\title{
Mammals of Kalimpong Hills, Darjeeling District, West Bengal, India
}

\author{
Jayanta Kumar Mallick
}

Wildlife Wing (Headquarters), Directorate of Forests, Government of West Bengal, Bikash Bhawan, North Block, Third Floor, Salt Lake City, West Bengal 700091, India Email: jayantamallick2007@rediffmail.com

Date of publication (online): 10 October 2012 Date of publication (print): 10 October 2012 ISSN 0974-7907 (online) | 0974-7893 (print)

Editor: L.A.K. Singh

\section{Manuscript details:}

Ms \# o2418

Received 04 March 2010

Final received 29 August 2012

Finally accepted 05 September 2012

Citation: Mallick, J.K. (2012). Mammals of Kalimpong Hills, Darjeeling District, West Bengal, India. Journal of Threatened Taxa 4(12): 3103-3136.

Copyright: () Jayanta Kumar Mallick 2012 Creative Commons Attribution 3.0 Unported License. JoTT allows unrestricted use of this article in any medium for non-profit purposes, reproduction and distribution by providing adequate credit to the authors and the source of publication.

Author Details: Jayanta Kumar Mallick postgraduated in 1974, joined the Wildlife Wing (Headquarters) in 1976 and has been working as PA to PCCF, Wildlife, West Bengal, for the last 37 years. Worked in the Project of the North-East India Task Force, IUCN/SSC/Elephant Specialist Group and also as project consultant of the Indian Society for Wildlife Research, Kolkata. He has been involved in all departmental publications, has participated in departmental workshops, undertaken a number of studies, is looking after departmental data bank and has more than hundred published articles, study reports, book and book-chapter on wildlife conservation, particularly of mammals.

Acknowledgements: The author expresses heartiest thanks to all those departmental field staff, officers and other respondents who shared their experiences for preparation of this study report. I am also grateful to Dr. Dipankar Ghose (WWF-I, New Delhi) for communicating his field observations. I am especially indebted to Indranil Mitra, GIS specialist, for providing digitized maps of the study area and Somnath Chakraborty for retrieving relevant data.
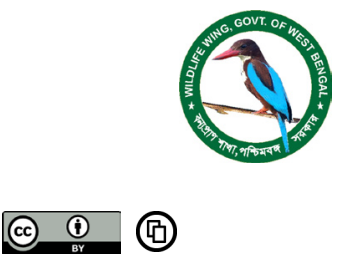

OPEN ACCESS | FREE DOWNLOAD
Abstract: Neora Valley National Park (NVNP) in the Kalimpong Hills, Darjeeling District, having a wide range of altitudinal variations (183-3,200 $\mathrm{m}$ ) and climatic conditions and forming an ecological trijunction with Sikkim and Bhutan, is the last virgin wilderness in West Bengal. It is a global hotspot for the unique ecosystem, where tropical, subtropical, temperate and sub-temperate forests represent a wealth of biodiversity including many threatened and rare mammals. It is the prime habitat of Ailurus fulgens (estimated population 28-32), Neofelis nebulosa (population unassessed), Ursus thibetanus (18), Bos gaurus (81), Hemitragus jemlahicus (32), Naemorhedus goral (73), Capricornis sumatraensis (89), Rusa unicolor (286), Muntiacus vaginalis (590) and Sus scrofa (615). Discovery of Panthera tigris (20) in 1998 prompted the forest department to include NVNP as a sensitive wildlife zone. Many authors recorded the mammalian diversity in Darjeeling District since the mid-nineteenth century, but most of them referred to the Darjeeling Hills. The documentations on Kalimpong Hills are scarce because of the dense canopy, thick undergrowth and inaccessible terrain, particularly in the pristine forests of Neora Valley. Consequently, a comprehensive compendium of the mammals in this region was not prepared. A study was undertaken in 2008-2009 with a view to bridging this knowledge-gap and presenting an updated account of the mammalian species in this new short-listed World Heritage Site and surrounding forests of the Kalimpong Hills based on literature review, questionnaire survey, direct sighting and indirect evidences. During June-October 1916, N.A. Baptista recorded 29 mammalian species (22 genera) out of 563 specimens collected, from the region. The present study registered 99 species (68 genera) after 94 years.

Keywords: Indirect evidences, Kalimpong, literature review, mammals, Neora Valley, sighting, status.

\section{INTRODUCTION}

The Indian mammals comprise of 401 species (180 genera, 45 families and 13 orders), constituting about $8.6 \%$ of the global mammalian species (Alfred et al. 2006). About $47 \%$ of the Indian mammals are recorded in West Bengal (Chakraborty \& Agrawal 1993). Whereas Ghosh (1992) recorded 217 species and subspecies of mammals (including the extinct species of the $20^{\text {th }}$ century) in the state, Agrawal et al. (1992) described 188 species and subspecies (103 genera, 33 families and 12 orders). Only two of them (Bengal Marsh Mongoose Herpestes palustris Ghose, 1965

Abbreviations: ATREE - Ashoka Trust for Research in Ecology and Environment; BNHM - Bengal Natural History Museum, Darjeeling; BSI - Botanical Survey of India; FD - Forest Division; IUCN - International Union for Conservation of Nature and Natural Resources; KFD - Kalimpong Forest Division; NP - National Park; NTFP - Non-Timber Forest Produce; NVNP - Neora Valley National Park; NESPON - North Eastern Society for the Preservation of Nature and Wildlife; SNR - Strict Nature Reserve; TE - Tea Estate; UNESCO - United Nations Educational, Scientific and Cultural Organization; WBFDCL - West Bengal Forest Development Corporation Limited; WLS - Wildlife Sanctuary; WWF-I/US - World-wide Fund for Nature-India/United States; ZSI - Zoological Survey of India. 
and Sombre Bat Eptesicus tatei Ellerman \& MorrisonScott 1951) are endemics (Mallick 2007, 2009).

The Indian Wildlife (Protection) Act, 1972 (as amended up to 2002) includes about 80 mammalian species in Schedule I, which are considered nationally 'threatened' (Anonymous 2003; Saha \& Mazumdar 2008). The Red Data List of Threatened Species (2008) of the International Union for Conservation of Nature and Natural Resources (IUCN) records 96 threatened species of mammals in India (Vié et al. 2009). According to Nandy (2006a), West Bengal harbours at least 24 globally threatened (eight 'Endangered' and 16 'Vulnerable') mammalian species. However, 70 species of mammals in the state require special attention for conservation (Saha et al. 1992).

Out of $11,879 \mathrm{~km}^{2}$ of recorded forests in West Bengal, Darjeeling district $\left(26^{0} 31^{\prime}-27^{0} 13^{\prime} \mathrm{N} \& 87^{0} 59^{\prime}-\right.$ $\left.88^{0} 53^{\prime} \mathrm{E}\right)$ occupies $1,204 \mathrm{~km}^{2}$ including Kalimpong sub-division $\left(556 \mathrm{~km}^{2}\right.$ or $\left.46.17 \%\right)$. But, in terms of the actual proportion of foliage cover, one-fourth of the geographical area $\left(3,148.74 \mathrm{~km}^{2}\right)$ of this district is forest (Mukherjee 1995), which is below the prescription of $60 \%$ coverage in the hills and mountains. But, owing to the great difference between the climatic conditions of the northern hills (Eastern Himalaya) and southern parts (foothills stretching down to the plains), Darjeeling District harbours a rich variety of flora (2,439 species) and fauna (4,166 species) (Alfred et al. 2004). Approximately, 72\% of West Bengal's mammal diversity is exhibited in Darjeeling Himalayan region, of which 53 species are not met with within other ecosystems of West Bengal (Chakraborty \& Agrawal 1993). Pradhan \& Bhujel (unpub.) listed 124 mammalian species in the Darjeeling Himalayas. While Agrawal et al. (1992) recorded 128 species, Mitra (2004) 180 species, and Sanyal et al. (2007) mentioned 126 species in Darjeeling.

NVNP combined with its adjoining forests in the Kalimpong Hills is the largest part in Darjeeling District with its wide range of environment gradients, supporting a unique, ecologically important and the most undisturbed patch of intact and well-preserved late succession forest (<http://education.vsnl.com/ bengaltiger $>$ downloaded on 15 January 2009). Neora Valley is designated as one of the key biodiversity areas in the Eastern Himalaya for mammals and birds (WWF-US, Asia Program 2005). This area falls in one of the global hotspots (Myers et al. 2000), Global
200 forest eco-regions (Olson \& Dinnerstein 1998), two endemic bird areas (Stattersfield et al. 1998) and several centres for plant diversity (Davis et al. 1995). It is also an integral part of the Kanchenjunga Landscape (Sharma \& Chettri 2005; Chettri et al. 2007a).

Historically, knowledge about the mammalian fauna of the Kalimpong Hills is rather patchy. The amateur naturalists, political and military officers and scientists like B.H. Hodgson (1845-1858), J.T. Pearson (1850), W. Theobald (1851, 1854), Major W.S. Sherwill (1852, 1853), W.T. Blanford (1857), T.C. Jerdon (1865), J. Anderson (1866-1869), Captain H.J. Elwes (1870-1871), Dr. F. Stoliczka (1871), W.S. Atkinson (1872), J. Gammie (1872), L. Mandelli (1872), Dr. G. King (1877), R.C. Wroughton (1891), collected many specimens from Darjeeling during the $19^{\text {th }}$ century. During the $20^{\text {th }}$ century, C.A. Crump (1914), H. Steven (1921, 1930), A. Linogreen (1938), R.L. Fernandez (1958), H.R. Bhat (1969), R.K. Ghose (1974-1985), P.K. Das (1979-1980), R.L. Choudhury (1980-1985) and others also collected specimens from Darjeeling District. But the present study area was not proportionately emphasized.

Recently, the fauna and flora have been studied in few parts of Neora Valley National Park (NVNP), but a large tract remains unexplored. Hence, an indepth study in the Kalimpong Hills (NVNP and $\mathrm{KFD}$ ) is considered to be of prime importance from conservation point of view.

\section{LITERATURE REVIEW}

The literature review reveals that most of the records of the mammals in Darjeeling District (Gray 1842; Tickell 1843; Horsfield 1851; Blyth 1863; Dobson 1876; Hunter 1876; Anderson 1881, 1912; Blanford 1891; Sclater 1891; Dalgliesh 1906; Pocock 1908; Shebbeare 1915, 1933; Thomas 1915, 1916a, b; Hinton 1922; Fry 1923; Matthews 1934; Dutt-Mazumdar 1955; Sur 1957; Khajuria 1959, 1966; Southwick et al. 1964; Ghose 1964, 1976, 1985; Ghose \& Ghosal 1969; Khajuria \& Ghose 1970; Topal 1970; Ghose \& Roy 1972; Sinha 1973, 1990; Mukherjee et al. 1980, 1982; Ghose \& Saha 1981; Tiwari 1982; Ghose \& Chakraborty 1983; Hill 1983; Chakraborty \& Ghose 1984; Biswas et al. 1985; Koopman 1989; Dasgupta 1991; Ghose \& Bhattacharya 1995; Mukherjee et al. 
1995; Bahuguna et al. 1998; Pradhan 1998, 1999, 2006; Mitra 2000a,b,c, 2001, 2002, 2003, 2003-2004; Pradhan et al. 2001a,b; Das 2003; Murmu et al. 2004; Mitra \& Alfred 2002, 2007; Bhattacharyya et al. 2008) refer to the mammals occurring in the Darjeeling Hills. In contrast, only a very few scientific studies on the mammals have been conducted in Kalimpong Hills.

The baseline for the present study is the first scientific research conducted in June-October 1916 by N.A. Baptista, who collected as many as 560 specimens of mammals belonging to 29 species under 22 genera from the dense mixed and bamboo forests of the Kalimpong Hills, east of the Teesta River, west of Ni-chu (Jaldhaka River) and Di-chu (tributary of the Jaldhaka) and bounded by Bhutan on the north (Wroughton 1917b). It appears that these fairly large collections did not attribute a corresponding wide range of the mammalian species, as found in the Sikkim-Bengal 'terai', Darjeeling Hills and Bhutan 'duars' (Wroughton 1916a,b, 1917a).

During the post-independence era, a range of 80 to 90 species of mammals in Kalimpong Forest Division (KFD) including Neora Valley have been recorded (Anonymous 1964), but, ironically, no supporting checklist was appended. West Bengal Forest Development Corporation Limited (WBFDCL) surveyed the eastern ridges of Neora Valley in 1979 and 1981 in a joint effort with Zoological Survey of India (ZSI) and Botanical Survey of India (BSI). In 1982, the Himalayan Club, Indian Army, ZSI and Department of Botany, University of Calcutta, in collaboration with KFD, organised an expedition from Lava to the uncharted western ridges. But no new records of mammalian species during these expeditions were reported.

During 11-18 April 1982, Dr. B. Biswas, R.K. Ghose and D.K. Ghosal of ZSI and K. Mukherjee of World Wide Fund for Nature-India (WWF-I) surveyed Samsing (Neora and Murti river valleys), Mouchowki, Rangpo and Tarkhola as part of their project on the lesser cats. But due to heavy rains, they could record only 17 mammalian species (Biswas \& Ghose 1982; Biswas et al. 1985). No lesser cat was, however, sighted by them, but the scat of an unidentified smaller cat was found on the bank of Neora River.

Sharma (1990) recorded 45 species of mammals in NVNP. In an account of the mammalian fauna of West Bengal, based mainly on the collections of ZSI as well as those recorded in the literature, Saha et al. (1992) listed 36 species (three Primates, 22 Carnivora, one Proboscidae, three Artiodactyla, and seven Rodentia) in NVNP.

The Department of Zoology, University of North Bengal in collaboration with the Department of Forests, Government of West Bengal and North Eastern Society for the Preservation of Nature and Wildlife (NESPON), an NGO based at Siliguri, Darjeeling, again surveyed the upper reaches and interior forests of NVNP during summer (April, May and June) and early winter (October) in 1994-1996 and prepared a checklist of 32 mammalian species (9 Schedule I) belonging to 16 families, representing more than 17 per cent of the total mammalian diversity in West Bengal (Biswas et al. 1999). Singhal \& Mukhopadhyay (1998) also reprinted the same checklist. Singhal (1999) added two new records of the mammals in NVNP.

WWF-India, Eastern Region (1997) recorded 17 mammalian species in the Upper Neora and Lower Neora Forest Ranges of NVNP as well as Chel, Lulagaon and Lava Forest Ranges of KFD. A study on the birds in the Lava (altitude 2,100m)-Lulagaon (altitude $1,575 \mathrm{~m}$ ) region of upper Neora during 20002001 reported direct and indirect evidences of the mammalian species like the Tiger, Leopard, Himalayan Black Bear, Red Panda, Himalayan Yellow-throated Marten, Wild Dog, Barking Deer, Assamese Macaque, Wild Boar, Moupin Pika (Dipankar Ghose \& Sujan Chatterjee pers. comm. 19 October 2009).

Chakraborty et al. (2008a) enlisted 25 species of mammals in NVNP on the basis of both sighting and indirect evidences. But Chakraborty et al. (2008b) recorded 16 mammalian species in NVNP, including sighting of seven species, collection of the scats of five species, observation of other signs of two species plus other two prey species. Ghosh et al. (2008) referred to eight key species of mammals in this area. UNESCO World Heritage Centre (2009) cited 19 mammalian species in NVNP. Bahuguna \& Mallick (2010) also mentioned 50 species of mammals in NVNP and surrounding areas. 


\section{MATERIALS AND METHODS}

\section{Study area}

This study was carried out during 2008-2009 in two administrative units in the Kalimpong subdivision (geographical area $1,056.5 \mathrm{~km}^{2}$ ) of Darjeeling District (see Images 1 and 2):

(1) $\operatorname{KFD}\left(26^{0} 51^{\prime}-27^{0} 12^{\prime} \mathrm{N} \& 88^{0} 28^{\prime}-88^{0} 56^{\prime} \mathrm{E}\right)$ under WBFDCL is bounded on the north by Sikkim (India) and Bhutan, on the east by Jaldhaka River(bordering Bhutan), on the south by the Jalpaiguri District (western duars) and on the west by Teesta River (bordering Sikkim). The land consists of numerous valleys with moderate to precipitous slopes. Here the forest was commercially exploited at random, causing loss of density and fragmentation.

(2) The only wildlife protected area in this region is NVNP $\left(88 \mathrm{~km}^{2}\right)$ having different altitudes $(183 \mathrm{~m}$ in the plains to $3,200 \mathrm{~m}$ in the hills). It is one of the oldest reserve forests (1881) in India, located near the ecological trijunction of West Bengal, Sikkim
(India) and Bhutan on the north and northeast, which is about $25 \mathrm{~km}$ east of Kalimpong Town (26052'03"$\left.27^{0} 7^{\prime} 35^{\prime} \mathrm{N} \& 88^{\circ} 45^{\prime}-88^{0} 50^{\prime} \mathrm{E}\right)$. The highest point is Rechila Danda (peak) (3,170m). A tabletop with two very shallow ponds (Jorepokhri) in the middle is also located in Thosum block of East Nar.

Originally, the study area was under the Sikkim kingdom, and conquered by the king of Bhutan in 1706. Practically, the whole area was then under forest, but was subsequently degraded due to jhooming. In 1864, the British captured this region and a large tract of the forest was clearfelled for rapid development of the agriculture and introduction of the tea, cinchona and orange plantations. However, Neora Valley was put under protection and unworkable working circle. Hence, this park is still virgin in nature providing an undisturbed habitat for the wildlife. Small patches of meadow and intervening patches of grassy or naked plains or rocky slopes are found here.

The zoogeographical significance of the study area is noteworthy. In spite of being located in the

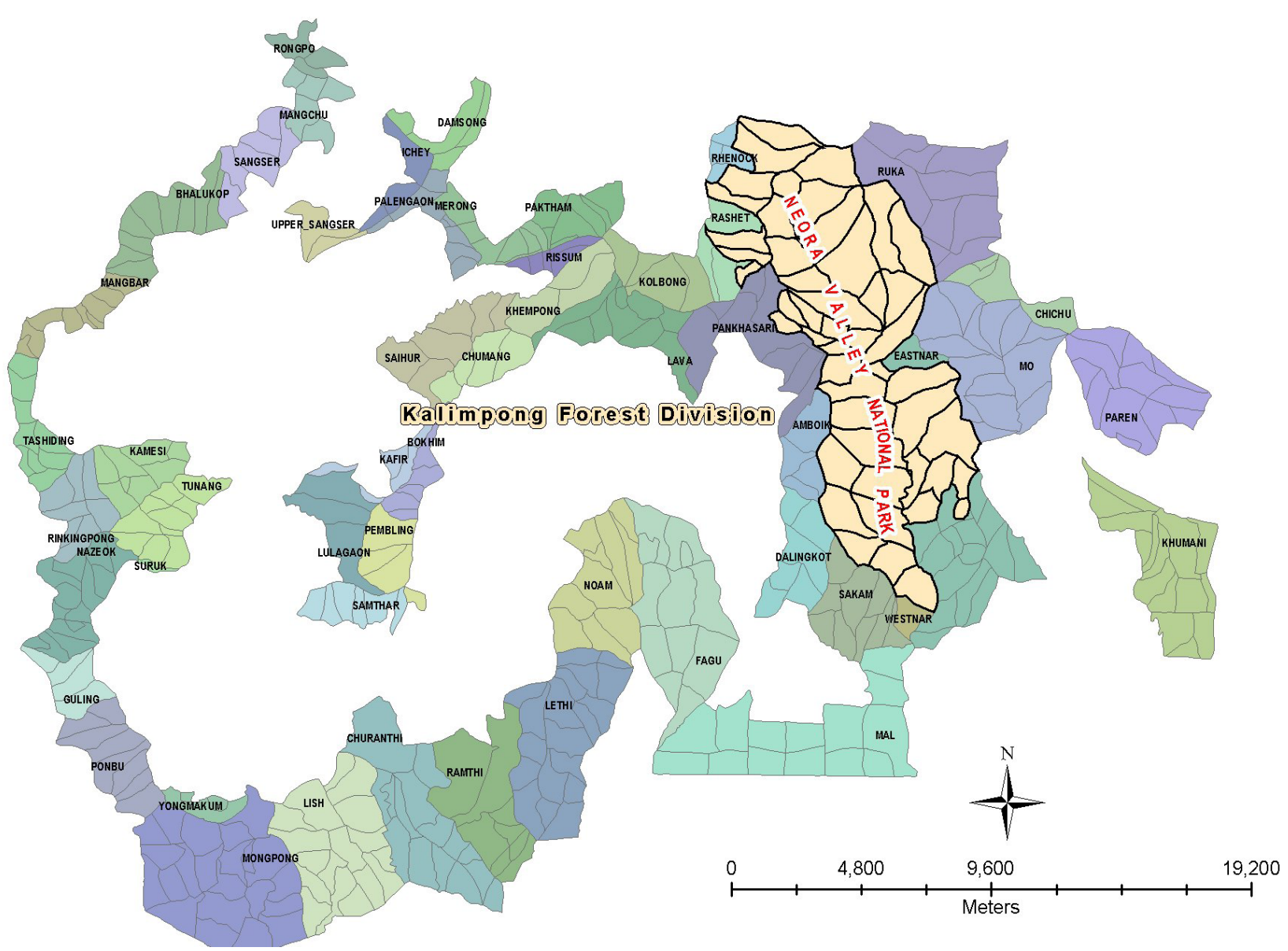

Image 1. Kalimpong Forest Division and important sites within Kalimpong Hills" 


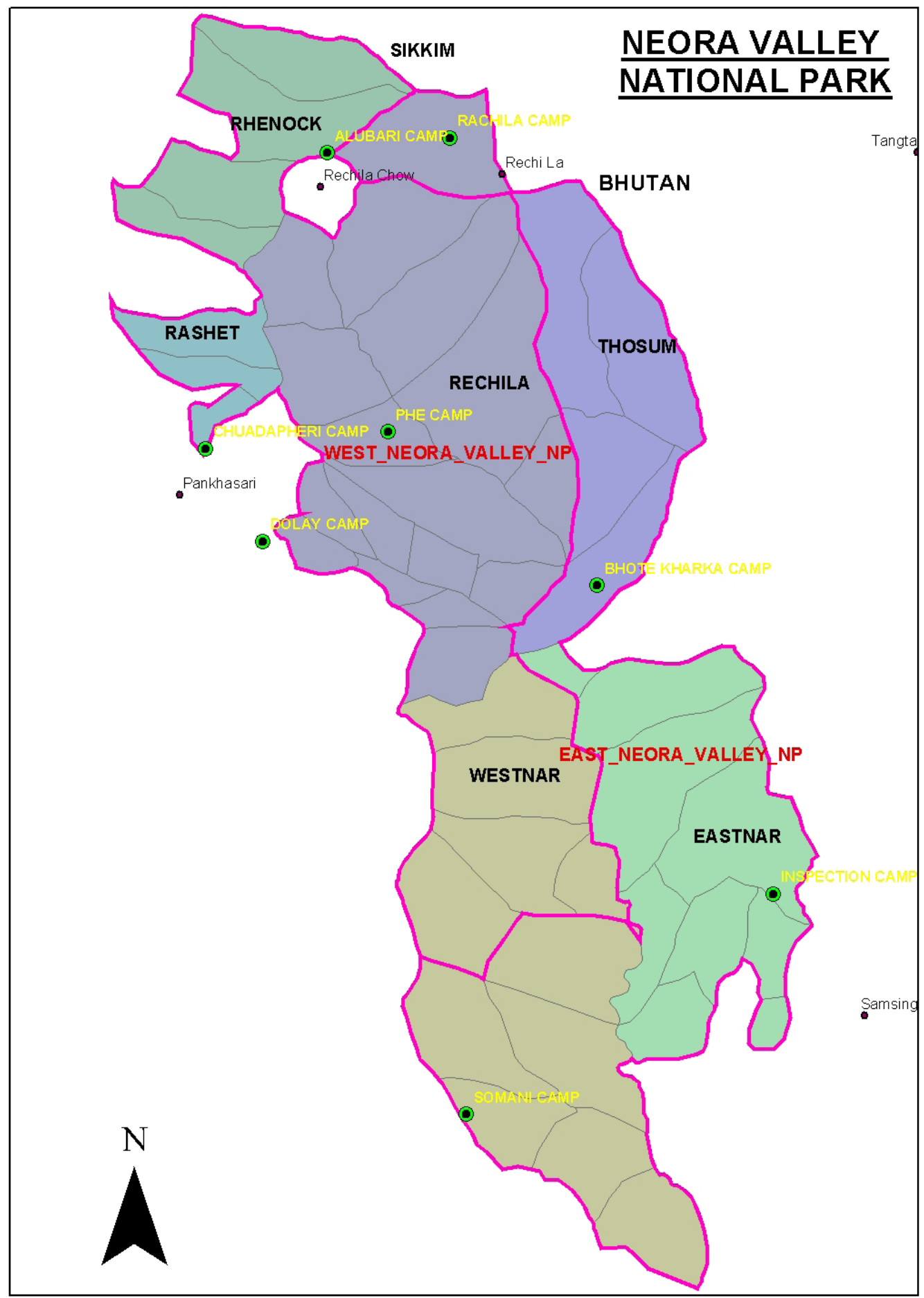

Image 2. Neora Valley National Park

Oriental Region, NVNP has some floral and faunal similarities with the Palaearctic Region of the adjacent zoogeographic zone. Moreover, it has characteristics of all the three subregions, namely Himalayan Montane System, Indian Peninsular subregion and the Malayan subregion (Singhal \& Mukhopadhyay 1998).
Cowan (1929) and Anonymous (1968) described the forest resources of the KFD. The forest type in this study area corresponds to 3C/C3b- "East Himalayan moist mixed deciduous forest" (Champion \& Seth 1968). It covers two biomes, namely Sino-Himalayan Temperate Forest (Biome-7) from 1,800-3,600 m and 
Sino-Himalayan Subtropical Forest (Biome-8) from 1,000-2,000 m (Islam \& Rahmani 2004).

NVNP exhibits a rich variety of habitats, as the area comprises the catchment and watershed of Neora River with its tributaries. Four habitat types are recognized, namely (i) subtropical mixed broadleaf forest, (ii) lower temperate evergreen forest, (iii) upper temperate mixed broadleaf forest, and (iv) Rhododendron forest. The density of vegetation is generally $>0.4$ except at Rechila Chawk, which was deforested in 1879.

Majumdar et al. (1984) enumerated 45 fern, 154 angiosperm and one gymnosperm species in the virgin Neora Valley. Rai \& Das (2004) recognize 83 medicinal, 59 edible, 18 ornamental, 21 poisonous (irritants and lethal), and 11 plants having fascinating assorted ethnic uses. NVNP is the home to several endemic orchids (UNESCO World Heritage Centre 2009). It is also famous for medicinal plants (PRAGYA 2007), particularly the Jaributi area. Ninety four species of birds, 276 species of insects and 38 species of other invertebrates have been identified in NVNP (Mukhopadhyay 1996; Singhal \& Mukhopadhyay 1998).

In terms of the biodiversity value, Neora Valley was urgently in need of conservation (Gadgil \& MeherHomji 1987). Hence, it was notified as a national park in April 1986 and finally gazetted in December 1992. It is now under the administrative control of Wildlife Division-II. In May 2009, NVNP was included in the shortlist of the World Heritage sites (UNESCO World Heritage Centre 2009; Mallick 2010a).

\section{Ecological Corridors}

NVNP along with its adjoining forests is considered as an important ecological corridor for movement of different species, such as the carnivores like the Tiger, Himalayan Black Bear, Clouded Leopard, Wild Dog, etc. and herbivores like the Asian Elephant and Indian Gaur, ungulates as well as several large-bodied bird species.

The salt lick at Rongpo on the left bank of Nuxal Khola was a rendezvous for the herbivorous animals coming from adjoining Bhutan, the foothill forests of Kalimpong and the farthest end of the Tondu forests of Jalpaiguri District till extensive clear-felling along the game-paths (corridors) and establishment of a forest village close to this salt lick during World WarII (Gupta 1958).
For re-establishing natural connectivity of the protected areas in the Eastern Himalaya, Chettri et al. (2007b) identified two conservation corridors linking NVNP:

1. Mahananda WS (26055'33"-26047'54'N \& 88 $33^{\prime} 31^{\prime \prime}-88^{\circ} 23^{\prime} 36^{\prime \prime}$ ) and

2. Toorsa Strict Nature Reserve (SNR) of Bhutan $\left(27^{\circ} 21^{\prime} \mathrm{N} \& 89^{\circ} 4^{\prime} \mathrm{E}\right)$ linked to Jigme Dorji NP $\left(27^{\circ} 55^{\prime} \mathrm{N}\right.$ $\left.\& 89^{\circ} 42^{\prime} \mathrm{E}\right)$.

Besides, Pangolakha WS $\left(128 \mathrm{~km}^{2}\right)\left(27^{0} 16^{\prime} 40.11^{\prime \prime} \mathrm{N}\right.$ \& 88 $\left.46^{\circ} 48.18^{\prime \prime} \mathrm{E}\right)$ of Sikkim is also located close to NVNP. There is also connectivity from the river Jaldhaka (northeastern part of the study area) to Arunachal Pradesh in the east of Bhutan through Toorsa SNR $\left(650.74 \mathrm{~km}^{2}\right)$, Jigme Dorji NP $\left(4,349 \mathrm{~km}^{2}\right)$, Thrumshingla NP $\left(768 \mathrm{~km}^{2}\right)$ to Bomdeling NP $\left(1,486.75 \mathrm{~km}^{2}\right)$ (Wangchuk 2007).

The southern boundary of NVNP, adjoining the forests of Jalpaiguri District, has connectivity with Chapramari WS (9.60km²) (26053'52”N \& 88051'1'E) and Gorumara NP $\left(79.45 \mathrm{~km}^{2}\right)\left(26^{\circ} 49^{\prime} \mathrm{N} \& 88^{\circ} 52^{\prime} \mathrm{E}\right)$.

The forests of Baikunthapur FD (26.46'48'N \& 88 $30^{\prime} 54^{\prime \prime}$ ) , partly in Darjeeling and partly in Jalpaiguri districts, which has gradually developed a micro habitat for the herbivores and carnivores, is also linked with the forests of KFD as well as Mahananda WS and also serves as a corridor for the migrating wild Elephants and Gaurs in particular.

\section{Data Collection Sites}

The following 30 sites were surveyed April 2008 to March 2009 for sighting of the mammals and obtaining their indirect evidences (footmarks, scats, scrapes, calls, kills, droppings and remnants of floral food items and other field signs) as well as verifying the known facts or secondary data:

(1) Algara (6km from Lava) $\left(27^{0} 5-27^{0} 7^{\prime} \mathrm{N} \&\right.$ 88 33 -88 $38^{\prime} \mathrm{E}$; $\left.1,780 \mathrm{~m}\right)$; (2) Alubari $\left(27^{\circ} 07^{\prime} \mathrm{N} \&\right.$ $88^{\circ} 43^{\prime} \mathrm{E}$; 2,538m); (3) Choudapheri $\left(27^{\circ} 05^{\prime} \mathrm{N}\right.$ \& $\left.88^{\circ} 42^{\prime} \mathrm{E} ; 2,372 \mathrm{~m}\right)$; (4) Chunabhati $\left(26^{0} 52-26^{0} 55^{\prime} \mathrm{N}\right.$ \& 88 $\left.8^{0} 31-88^{0} 36^{\prime} \mathrm{E}\right)$; (5) Dalingkot $\left(26^{0} 58-27^{0} 1^{\prime} \mathrm{N}\right.$ \& 88 $\left.88^{\circ} 42-88^{\circ} 44^{\prime} \mathrm{E}\right)$; (6) East Nar $\left(27^{\circ} 01-27^{\circ} 03^{\prime} \mathrm{N}\right.$ \& 88 $\left.45-88^{\circ} 46^{\prime} \mathrm{E}\right)$; (7) Ghish (26 $53-26^{\circ} 58^{\prime} \mathrm{N} \& 8^{\circ} 34$ $\left.88^{0} 39^{\prime} \mathrm{E}\right)$; (8) Gorubathan $\left(26^{0} 55-26^{0} 57^{\prime} \mathrm{N} \& 8^{0} 39\right.$ $\left.88^{\circ} 42^{\prime} \mathrm{E} ; 417 \mathrm{~m}\right)$; (9) Jorepokhri (2708’ $\mathrm{N} \& 88^{\circ} 44^{\prime} \mathrm{E}$; $3,170 \mathrm{~m})$; (10) Kalimpong $\left(26^{0} 59-27^{0} 2^{\prime} \mathrm{N} \& 8^{0} 26-\right.$ $\left.88^{0} 29^{\prime} \mathrm{E} ; 1,249 \mathrm{~m}\right)$; (11) Khumani $\left(27^{\circ} 0-27^{0} 57^{\prime} \mathrm{N}\right.$ \& 88 $49-88^{\circ} 52^{\prime} \mathrm{E}$ ); (12) Lava (western gateway to 
NVNP) $\left(27^{\circ} 02-27^{0} 07^{\prime} \mathrm{N} \& 88^{\circ} 36-88^{\circ} 41^{\prime} \mathrm{E} ; 2,200 \mathrm{~m}\right)$; (13) Lulagaon $\left(26^{0} 59-27^{0} 2^{\prime} \mathrm{N}\right.$ \& 8 88 $31-88^{\circ} 34^{\prime} \mathrm{E}$; $1,575 \mathrm{~m})$; (14) Mo $\left(27^{\circ} 02-27^{0} 05^{\prime} \mathrm{N} \& 88^{\circ} 45-88^{\circ} 49^{\prime} \mathrm{E}\right)$;

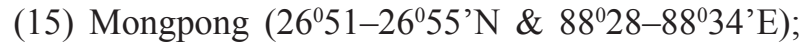
(16) Mouchowki (1,311m), 12km north of Samsing; (17) Nimbong (26059'N \& 88 $8^{\circ} 33^{\prime} \mathrm{E}$; 1,372m); (18) Pankhasari $\left(27^{\circ} 02-27^{\circ} 05^{\prime} \mathrm{N} \& 88^{\circ} 40-88^{\circ} 43^{\prime} \mathrm{E}\right)$; (19) Pedong $\left(27^{0} 2^{\prime} \mathrm{N} \& 88^{\circ} 20^{\prime} \mathrm{E}\right.$; 1,432m); (20) Rashet $\left(27^{0} 05-27^{\circ} 07^{\prime} \mathrm{N} \&\right.$ \& 88 $\left.8^{\circ} 42-88^{\circ} 44^{\prime} \mathrm{E}\right)$; (21) Rechila (Chawk) including Jaributi $\left(27^{\circ} 05-27^{\circ} 07^{\prime} \mathrm{N} \quad \&\right.$ $88^{\circ} 43-88^{\circ} 45^{\prime} \mathrm{E}$; $\left.3,170 \mathrm{~m}\right)$; (22) Rhenock $\left(27^{\circ} 07^{\prime} \mathrm{N} \&\right.$ $\left.88^{\circ} 43^{\prime} \mathrm{E}\right)$; (23) Rishyap (10km from Lava) (2,850m); (24) Samsing (eastern gateway to NVNP), situated on the north-south ridge between the Neora River on the west and the Murti River on the east (2658$\left.27^{\circ} 2^{\prime} \mathrm{N} \& 88^{\circ} 45-88^{\circ} 48^{\prime} \mathrm{E}\right)$; (25) Sangser $\left(27^{\circ} 06^{\prime} \mathrm{N} \&\right.$ $88^{\circ} 31^{\prime} \mathrm{E}$; 1,097m); (26) Suntalekhola (southeastern edge of NVNP, $3 \mathrm{~km}$ from Samsing; 750m); (27) Tarkhola $\left(27^{\circ} 05-27^{0} 10^{\prime} \mathrm{N} \& 8^{0} 27-88^{0} 33^{\prime} \mathrm{E}\right.$; $\left.325 \mathrm{~m}\right)$; (28) Thosum $\left(27^{\circ} 04-27^{\circ} 05^{\prime} \mathrm{N} \& 88^{\circ} 45-88^{\circ} 46^{\prime} \mathrm{E}\right)$; (29) West Nar $\left(27^{\circ} 01-27^{\circ} 2^{\prime} \mathrm{N} \& 88^{\circ} 43-88^{\circ} 45^{\prime} \mathrm{E}\right)$ and (30) Zero Point on NVNP road $\left(27^{0} 5^{\prime}\right.$ N \& 88 $88^{\circ}$ 'E; $2,500 \mathrm{~m}$ ). The Tea Estates (TEs) and revenue villages in the fringe or impact area were also traversed for eliciting relevant data.

In addition, eight forest trails were trekked. These were: (1) Choudapheri [the first forest check post, $14 \mathrm{~km}$ from Lava] trail along the mountain ridges of Rashet and Rechila blocks (18km); (2) ChoudapheriAlubari trail via Zero Point and PHE source [16km (13km through the dense forest and $3 \mathrm{~km}$ through the valley)]; (3) Alubari-Jorepokhri trail (5km); (4) Mouchowki-Bhote Kharka trail $(7 \mathrm{~km})$; (5) road from Lava Village towards Algarah (highest point 2,370m)/Kalimpong; (6) trail along the ridge towards Tiffindara; (7) road from Lulagaon along the Heritage Site to Jhandidara $(1,824 \mathrm{~m})$ under East Nar-21; and (8) Suntalekhola-Lava trail, leading steeply through the thick broadleaved tropical and semi-tropical forests via Mouchowki, Rechila top, Alubari and Pankhasari Ridges.

Besides, the field stations (camps) like Red Panda (Choudapheri); Mulkharga (on the way to Rhenock); Rechila and Alubari (at Rechila Chawk); Tiger; Orchid; Maple; Betula; Doley; Somani; PHE; Sakam; Mouchowki and Bhote Kharga (Thosum-1) were also visited for collection of data.

Moreover, the wetlands used by the wildlife in
NVNP, namely Jorepokhri at the trijunction of West Bengal, Sikkim and Bhutan (27 $\left.7^{\circ} \mathrm{N} \& 8^{\circ} 44^{\prime} \mathrm{E}\right)$, Panchpokhri, Tempola, etc. were also visited for data collection.

\section{Methods}

There were no watchtowers in NVNP when the study was undertaken. It was also very difficult to penetrate through the dense forest in any particular straight line or direction. Moreover, it was not possible to carry out surveys along fixed transects in the inaccessible terrain. Hence, transects of varying lengths were laid along the small kholas (streams) and existing forest trails (bridle paths and trekking routes), covering different habitats as far as possible. The entire length of each trail was trekked during the daytime (in between early morning and late afternoon). A few mammals were seen crossing these trails. While inspecting the trails thoroughly at an interval of about $500 \mathrm{~m}$, patches of size about $10 \times 10 \mathrm{~m}$ were randomly checked for finding the indirect evidences of the mammals. In addition, suitable area of approximately $2 \mathrm{~km}$, lying on either side of the camp locations, was also searched for in the evening with battery-operated spotlights.

The forest floor in the remote areas being mostly rocky and covered with thick leaf litter, the pug marks, scats and animal signs were also searched for on the sandy or clayey beds of streams and rivers, open spaces and tree trunks. Caves, rock-crevices, burrows and other natural holes were also examined for this purpose.

There is no doubt that differentiating scats of carnivores based on their measurements, especially where many species co-exist, can be difficult (Johnson et al. 1984). To overcome the difficulties, presently Thin Layer Chromatography (TLC) has been adopted for scat identification of different carnivore species (Major et al. 1980; Johnson et al. 1984; Athreya \& Johnsingh 1995). Owing to lack of infrastructural facilities, identification of scats collected during the present study was carried out on the basis of diagnostic characters, such as the size, shape and odour, field experience of the forest staff and the traditional knowledge of the local people as was done by Chakraborty et al. (2008a,b). Hair samples of the scats were identified by comparing the materials present in ZSI. 
As most of the mammals of NVNP and surrounding forests are shy, nocturnal and live in the dense canopy and thick undergrowth (visibility not more than $5-10 \mathrm{~m}$ and often less than $2 \mathrm{~m}$ on either side), direct sighting of the mammalian species during daytime was very limited. So, the people living inside and fringe of the forests and departmental staff attached to the camps and engaged in regular monitoring in the study area $(n=100)$ were also interviewed (semi-structured questionnaire survey) with colour photographs of the mammalian species for identification.

\section{RESULTS}

The mammalian species registered in the study area are described below.

Order: Eulipotyphla Waddell, Okada \& Hasegawa, 1999: Insect-eaters or Insectivores (Shrews, Moles and Hedgehogs)

Family: Soricidae Fischer von Waldheim, 1817: Shrews

Subfamily: Soricinae Fischer von Waldheim, 1817: Red-toothed Shrew

Genus: Episoriculus Ellerman \& Morrison-Scott, 1966: Brown-toothed Shrew

1. Episoriculus caudatus caudatus Horsfield, 1851: Hodgson's Brown-toothed Shrew (Wroughton 1917b; Agrawal et al. 1992).

This shrew is common in the montane coniferous and alpine forests as well as rhododendron forests and alpine meadows along the riverside at altitudes from $1,800-3,200$ m. N.A. Baptista collected two females at Sangser. The fur in specimens from Darjeeling District was reported to be shorter and less dense than those in specimens from Sikkim. Since it is a nocturnal animal, its sighting is rare in the study area. It was not sighted during the recent surveys.

Genus: Soriculus Blyth, 1854: Southern Longtailed Shrew

2. Soriculus nigrescens nigrescens Gray, 1842: Himalayan Black Ground or Burrowing Longclawed or Mouse-tailed Forest Shrew (Sharma 1990; Agrawal et al. 1992; Mukhopadhyay 1996, Singhal \& Mukhopadhyay 1998; Biswas et al. 1999; Chaudhuri \& Sarkar 2003).

This nocturnal shrew of the temperate forests inhabits the damp areas in shrub lands in the outskirts of evergreen broad-leaved and coniferous forests at elevations from $1,219-1,800 \mathrm{~m}$ of the upper forest zone and naked rocky areas. Once upon a time it was a common species in the study area. This shrew was sighted at Jaributi and specimens were also trapped with baits in deep forest, near old fallen trees in the same area during the recent surveys.

Subfamily: Crocidurinae Milne-Edwards, 1872: White-toothed Shrew

Genus: Suncus Ehrenberg, 1833: House Shrews, Musk Shrews

3. Suncus murinus soccatus Hodgson, 1845: Grey Musk Shrew or House Shrew (Wroughton 1917b; Sharma 1990; Agrawal et al. 1992; Downloaded on 20 October 2009).

This nocturnal shrew is commonly found in the forests as well as near the human settlements. Some of the species live in leaf litter or grass. Some have been recorded up to $2,825 \mathrm{~m}$. N.A. Baptista collected 15 males and 26 females from Kalimpong, two males from Nimbong, five males and five females from Pedong and one male from Sangser. H. Khajuria also collected two males and two females from Tarkhola in 1958. Though recorded earlier in NVNP, it was not sighted during the recent surveys.

Family: Talpidae Fischer von Waldheim, 1817: Moles

Subfamily: Talpinae Fischer von Waldheim, 1817: Old World Moles and relatives

Genus: Euroscaptor Miller, 1940: Eurasian Moles

4. Euroscaptor micrura micrura Hodgson, 1841: Eastern Short-tailed Mole (Sharma1990).

This species is usually found in tropical and subtropical montane forest between 1,000-2,000 m and lives in leaf litter and rocky, gravelly areas. It is recorded as common in NVNP, but was not sighted during the recent survey, though some tunnels were observed in the forest edges and bamboo brakes.

Order: Scandentia Wagner, 1855: Tree-shrews

Family: Tupaiidae Gray, 1825: Tree-shrews

Subfamily: Tupaiinae Gray, 1825: True treeshrews

Genus: Tupaia Raffles, 1821: True tree-shrews

5. Tupaia belangeri lepcha Thomas, 1922: Common Northern or Assam Tree-shrew (Wroughton, 1917b; Sharma 1990; Agrawal et al. 1992; Chaudhuri \& Sarkar 2003; <http://zsienvis.nic.in/biodiversity_ wb/Fauna/ 43.\%20Mammal. doc $>$ downloaded on 20 
October 2009).

This species was formerly included as a subspecies of Tupaia glis, until recent chromosomal studies. It represents a species complex with a distinct northern form in China (Han et al. 2008).

Presence of this diurnal tree-shrew was reportedly observed on the ground level, though individuals were occasionally sighted on tree branches of the understorey of the forest. N.A. Baptista collected two males from Nimbong. It is a rare tree-shrew and was found in Kalimpong during the recent surveys. Though earlier recorded in NVNP, it was not found there.

Order: Chiroptera Blumenbach, 1779: Bats

Suborder: Megachiroptera Dobson, 1875: Large Old World Fruit Bats and Flying Foxes

Family: Pteropodidae Gray, 1821: Fruit Bats and Flying Foxes

Subfamily: Pteropodinae Gray, 1821: True Fruit Bats and Flying Foxes

The fruit bats are common in the valleys and met with at lower elevation up to $1,698 \mathrm{~m}$.

Genus: Cynopterus Cuvier, 1824: Short-nosed or Dog-faced Fruit Bats

6. Cynopterus sphinx sphinx Vahl, 1797: Greater Short-nosed Fruit Bat or Short-nosed Indian Fruit Bat (Sharma 1990; Agrawal et al. 1992; Das 2003; $<$ http://zsienvis.nic.in/biodiversity_wb/Fauna/43.\%20 Mammal.doc $>$ downloaded on 20 October 2009).

In the past, these bats were very common in the study area. R.L. Choudhury and R.K. Ghose collected 11 males and eight females from Chunabhati (near Kalimpong) (in 1978 and 1980 respectively). R.K. Ghose also collected one male and one female from Gorubathan in 1981 and four males and seven females from Khumani in 1985. Though earlier recorded, this nocturnal bat was not seen during the recent surveys in NVNP or surrounding forests.

Genus: Rousettus Gray, 1821: Rousettes or Russet Flying Foxes

7. Rousettus leschenaulti leschenaulti Desmarest, 1820: Leschenault's Rousette or Indian Fulvous Fruit Bat (Wroughton 1917b; Sharma 1990; Agrawal et al. 1992; Das 2003; <http://zsienvis.nic.in/biodiversity _ wb/Fauna/43.\%20 Mammal.doc $>$ downloaded on 20 October 2009).

This fruit bat is found up to $2,100 \mathrm{~m}$ altitude. It was reported to be very common in the past. R.K. Ghose collected two females from Gorubathan in
1981 and $\mathrm{H}$. Khajuria collected one juvenile male and one female from Tarkhola in 1958. N.A. Baptista also collected one male and five juvenile females from Pedong. Though earlier recorded, this nocturnal bat was not sighted during the recent surveys in NVNP and surrounding forests.

Suborder: Microchiroptera Dobson, 1875: Insecteating Bats

Family: Rhinolophidae J.E. Gray, 1825: Horseshoe Bats

Subfamily: Rhinolophinae J.E. Gray, 1825: Typical Horseshoe Bats

Genus: Rhinolophus Lacépède, 1799: Rhinolophs

8. Rhinolophus lepidus monticola K. Anderson, 1905: Least or Mussoorie Horseshoe Bat (Wroughton 1917b).

Sinha (1973) considered monticola a distinct species. N.A. Baptista collected two males and 12 females from Nimbong, one female from Pedong and three males from Sangser. This nocturnal bat was not found during the recent surveys.

9. Rhinolophus luctus perniger Hodgson, 1843: Great Eastern Woolly Horseshoe Bat (Wroughton 1917b; Agrawal et al. 1992; Mukhopadhyay 1996, Singhal \& Mukhopadhyay 1998; Biswas et al. 1999; Das 2003; Chaudhuri \& Sarkar 2003; <http://zsienvis. nic.in/biodiversity_wb/Fauna/43.\%20Mammal.doc> downloaded on 20 October 2009).

N.A. Baptista collected one male from Nimbong. It is now a rare species in the study area. It was seen during the current survey at Rechila chawk in the evening. It was also found at Kalimpong.

10. Rhinolophus pusillus blythi K. Anderson, 1918: Least Horseshoe Bat (Wroughton 1917b; Agrawal et al. 1992; Bates \& Harrison 1997; Molur et al. 2002; $<$ http://zsienvis.nic.in/biodiversity_wb/Fauna/43.\%20 Mammal.doc $>$ downloaded on 20 October 2009).

N.A. Baptista collected two males and five females from Nimbong and two males from Sangser. It is also recorded from Kalimpong forests. However, this nocturnal bat was not sighted during the present survey.

11. Rhinolophus rouxii rouxii Temminck, 1835: Peninsular or Rufous Horseshoe Bat (Wroughton 1917b; Agrawal et al. 1992; Bates \& Harrison 1997; Molur et al. 2002; Das 2003; http://zsienvis.nic. in/biodiversity_wb/Fauna/43.\%20Mammal.doc > downloaded on 20 October 2009). 
N.A. Baptista collected six males from Nimbong and R.K. Ghose collected one male from Khumani in 1985. This nocturnal bat was not found during the present survey.

12. Rhinolophus sinicus K. Andersen, 1905: Andersen's Rufous Horseshoe Bat (Bates \& Harrison 1997; Molur et al. 2002).

In the past, this species was found at Nimbong. This nocturnal bat was not seen during the recent survey.

Subfamily: Hipposiderinae Lydekker, 1891: Round-leaf Horseshoe Bat

Genus: Hipposideros Gray, 1831: Round-leaf Horseshoe Bat

13. Hipposideros armiger armiger Hodgson, 1835: Hodgson or Great Himalayan Leaf-nosed Bat (Wroughton 1917b; Bates \& Harrison 1997; Molur etal. 2002; Das 2003; <http://zsienvis.nic.in/biodiversity wb/Fauna/43.\%20Mammal.doc $>$ downloaded on 20 October 2009).

N.A. Baptista collected two females from Nimbong. This bat was not seen during the recent survey.

14. Hipposideros cineraceus micropus Peters, 1872: Least Ashy Leaf-nosed Bat (Bates \& Harrison 1997; Molur et al. 2002; Das 2003)

N.A. Baptista collected one male and one female from Nimbong and one male and one female from Sangser. But during the recent survey this species could not be traced.

15. Hipposideros fulvus fulvus Gray, 1838: Bicoloured or Gray Fulvous Leaf-nosed Bat (Wroughton 1917b)

N.A. Baptista collected five males and 12 females from Nimbong and six males and nine females from Sangser. This species was not seen during the recent surveys.

16. Hipposideros pomona gentilis $\mathrm{K}$. Andersen, 1918: Andersen's Leaf-nosed Bat (Bates \& Harrison 1997; Molur et al. 2002)

This Leaf-nosed Bat was recorded earlier at Nimbong and Sangser, but was not observed during the recent survey.

Family: Vespertilionidae Gray, 1821: True Insecteating or Evening Bats

Subfamily: Vespertilioninae Gray, 1821: Vespertilionid Bats

Genus: Barbastella Gray, 1821: Barbastelle Bats
Hodgson, 1855: Eastern Barbastella (Wroughton, 1917b; Agrawal et al. 1992; Bates \& Harrison 1997; Molur et al. 2002; Das 2003).

N.A. Baptista collected six males and 12 females from Nimbong. It was not sighted during the recent survey.

Genus: Eptesicus Rafinesque, 1820: Serotine or Big Brown Bats

18. Eptesicus serotinus pachyomus Tomes, 1857: Common Serotine Bat (Mukhopadhyay 1996, Singhal \& Mukhopadhyay 1998; Biswas et al. 1999).

It is common in NVNP. This bat was sighted in the evening at Rechila chawk during the current survey.

Genus: Nyctalus Bowdich, 1825: Noctules

19. Nyctalus noctula labiatus Hodgson, 1835: Common Indian Noctule (Wroughton 1917b; Agrawal et al. 1992; Bates \& Harrison 1997; Molur et al. 2002; Das 2003; <http://zsienvis.nic.in/biodiversity_wb/ Fauna/43.\%20Mammal.doc> Downloaded on 20 October 2009).

N.A. Baptista collected two males from Sangsar. This species was not seen during the recent surveys.

Genus: Pipistrellus Kaup, 1829: Pipistrelles

20. Pipistrellus babu Thomas, 1915: Babu or Himalayan Pipistrelle (Agrawal et al. 1992; Das 2003).

This taxon is recognized as a subspecies or synonym of P. javanicus (Wilson \& Reeder 2005).

R.L. Chowdhury collected one female from Paperkheti (ca. $15 \mathrm{~km}$ north of Gorubathan) in 1980. This bat was not seen during the recent survey.

21. Pipistrellus coromandra coromandra Gray, 1838: Indian or Coromondel Pipistrelle (Wroughton 1917b; Agrawal et al. 1992; Das 2003; <http://zsienvis. nic.in/biodiversity_wb/Fauna/43.\%20Mammal.doc> downloaded on 20 October 2009).

N.A. Baptista collected two males and one female from Nimbong, 12 males and 26 females from Pedong, two males and one female from Kalimpong and two males from Sangser. R.L. Chowdhury also collected one male from Ranichera (c 9km south of Gorubathan) in 1980. It was not seen during the recent surveys.

22. Pipistrellus javanicus Gray, 1838: Javan's Pipistrelle (Bates \& Harrison 1997; Molur et al. 2002)

This species was recorded from Nimbong. This bat was not sighted during the recent surveys.

23. Pipistrellus mimus mimus Wroughton, 1899 
[synonym of $P$. tenuis in Wilson \& Reeder (2005)]: Indian Pygmy Pipistrelle (Sharma 1990)

It is reportedly common in NVNP, but was not sighted during the recent survey.

Genus: Tylonycteris Peters, 1872: Flat-headed Bats

24. Tylonycteris pachypus fulvida Blyth, 1859: Club-footed or Bamboo or Flat-headed Bat (Wroughton 1917b; Agrawal et al. 1992; Bates \& Harrison 1997; Molur et al. 2002; Das 2003; < http://zsienvis.nic. in/biodiversity_wb/Fauna/43.\%20Mammal.doc $>$ download on 20 October 2009).

N.A. Baptista collected six males and 15 females from Kalimpong, one male from Nimbong and one male from Sangser. It was not sighted during the recent surveys.

Subfamily: Murininae Miller, 1907: Murine or Tube-nosed Insectivorous Bat

Genus: Murina Gray, 1842: Tube-nosed Insectivorous Bats

25. Murina cyclotis cyclotis Dobson, 1872: Roundeared Tube-nosed Bat (Wroughton, 1917b)

John Thomas Pearson first sent the type specimen from Darjeeling. N.A. Baptista collected one male from Sangser. It was not seen during the recent survey.

26. Murina huttoni huttoni (Peters, 1872): Hutton's Tube-nosed Bat (Bates \& Harrison 1997; Molur et al. 2002)

A specimen from Sangser is kept in the museum of Bombay Natural History Society. This bat was not sighted during the recent survey.

27. Murina leucogaster rubex Thomas, 1916: White-bellied or Greater Tube-nosed Bat (Wroughton, 1917b; Agrawal et al. 1992; Bates \& Harrison 1997; Molur et al. 2002; Das 2003)

N.A. Baptista collected one male (skull missing) from Sangser. This bat was not sighted during the recent surveys.

28. Murina tubinaris Scully, 1881 (no sub-species determined): Scully's Tube-nosed Bat (Wroughton, 1917b).

S.A. Baptista collected three males from Sangser. It was not found during the recent survey.

Order: Primates: Lemurs, Monkeys and Apes

Family: Cercopithecidae Gray, 1821: Old World monkeys

Subfamily: Cercopithecinae Gray, 1821: Baboons,
Macaques, Mangabeys and relatives

Genus: Macaca Lacépède, 1799: Asiatic Macaques (Khajuria 1966; Fooden 1982)

Rhesus Macaques and Assameese Macaques are sympatric in the study area and were often seen in troops side by side at Tarkhola, but not seen to mix together.

29. Macaca assamensis pelops Hodgson, 1841: Western Assamese Macaque (Khajuria 1966; Khajuria \& Ghose 1970; Fooden 1982; Biswas \& Ghose 1982; Sharma 1990; Agrawal et al. 1992; Saha et al. 1992; WWF-India Eastern Region 1997; Mitra 2000a, b, c; 2001; Chaudhuri \& Sarkar 2003; Prince 2003; Molur et al. 2003; Dey 2009; <http://www.kolkatabirds. com/netrip1.htm $>$ downloaded on 12 October 2009; $<$ http://zsienvis.nic.in/biodiversity_wb/Fauna/43.\%20 Mammal.doc $>$ downloaded on 20 October 2009; $<$ http://www.birdtours.co.uk/tripreports/india/ india11/list.htm $>$ downloaded on 6 September 2009)

These are dominant diurnal animals and fairly common in the study area. But it is practically absent above 2,500m altitude. During winters, they descend to the lower elevations.

R.L. Fernandez collected one juvenile male and two females from Tarkhola in 1958. In both the female specimens collected from Tarkhola, a well-defined whorl on the vertex was present, which normally is not found in the Assamese Macaque (Agrawal et al. 1992). It was earlier recorded at Samsing, Mouchowki, Dalingkot and Sangser. In NVNP, a fairly good number was found at lower elevation during the recent surveys. These monkeys were also seen on the way to Suntalekhola and quite frequently in small numbers by the roadside at Lava and Zero Point. At Tarkhola, this macaque reportedly frequented villages surrounded by mainly Sal Shorea robusta and Teak Tectona grandis forest and fearlessly raided the maize fields.

30. Macaca mulatta mulatta Zimmermann, 1780 [In the most authoritative review till date, Fooden (2000) concluded that no subspecies of Macaca mulatta is recognizable]: Rhesus Macaque (Saha et al. 1992; WWF-I Eastern Region 1997; Chaudhuri \& Sarkar 2003; Molur et al. 2003; Chakraborty et al. 2008b; Dey 2009; <http://www.birdtours.co.uk/ tripreports/india/india11/list.htm $>$ downloaded on 6 September 2009; <http://www.kolkatabirds.com/ netrip1.htm $>$ downloaded on 12 October 2009)

The Rhesus Macaque is well spread and common 
in the Kalimpong Hills. Sightings of this diurnal animal were recorded in the lower elevation of NVNP like Samsing. During the current survey, tracks and droppings of this monkey were also noticed in plenty on the wet sandy patches around the Neora River, Ashalary khola, Sakam khola, Dhoula khola, etc. The droppings are green-brown in colour containing more leaf stems. It is practically absent above $2,500 \mathrm{~m}$. A troop of 20-30 was recorded at the Mahakal temple, Lava and adjacent areas during the recent survey.

Subfamily: Colobinae Jerdon, 1867: Colobus Monkeys, Leaf-monkeys and relatives

Genus: Semnopithecus Desmarest, 1822: Indian Purple-faced Langurs

31. Semnopithecus hector Pocock, 1928: Terai Gray Langur (Saha et al. 1992; Mukherjee et al. 1995; WWF-India, Eastern Region 1997; Chaudhuri \& Sarkar 2003; Brandon-Jones 2004).

$S$. hector was formerly recognized as a subspecies of $S$. entellus, but it is now considered a distinct species (Molur \& Chhangani 2008). This langur was found scattered at lower elevations in the study area, as it is exceptionally susceptible to cold. In 1980, two troops consisting of three and 16 individuals of this diurnal langur were observed near the Coronation Bridge on the River Teesta at Sevok, which is the southern borderline of the study area. WWF-India, Eastern Region (1997) recorded this species as very rare at Lava. No other records of this species in the study area are available. It is also not sighted during the present survey.

Order: Carnivora Bowdich, 1821: Flesh-eaters or Carnivores

Family: Canidae Fischer, 1817: Canines/Dogs, Wolves, Foxes

Genus: Canis Linnaeus, 1758: Wolves and Jackals

32. Canis aureus indicus Hodgson, 1833: Golden Jackal (Wroughton 1917b; Sharma 1990; Agrawal et al. 1992; Saha et al. 1992; Mukhopadhyay 1996, Singhal \& Mukhopadhyay 1998; Chaudhuri \& Sarkar 2003; <http://www.his-india.org.au/ kalimpong.html> downloaded on 28 October 2009; <http://zsienvis. nic.in/ biodiversity_wb/Fauna/43.\%20Mammal.doc > downloaded on 20 October 2009).

The Golden Jackal is found both in the lower and higher elevations in the study area. N.A. Baptista collected one male and one female from Pedong. Specimens from the hilly areas are much darker than those of the plains. It is mainly a nocturnal animal. It was not sighted during the recent survey. Reportedly the jackals, at times, attack the rural dogs and the livestock. Its population has reportedly declined in this region, particularly due to retaliatory killings and annual tribal hunting.

33. Canis indica R.K. Aggarwal et al. 2007 (Research of the mtDNA)

Mitochondrial DNA is the DNA located in organelles called mitochondria, structures within cells that convert the energy from food into a form that cells can use of this species, formerly Canis lupus pallipes (it is now treated as a new species): Small Indian Wolf (Saha et al. 1992; Chaudhuri \& Sarkar 2003)

The Small Indian Wolf inhabits a wide variety of habitats including coniferous and deciduous forests, but has been extirpated from much of its former range in the study area and it is very rare now. This species was reportedly sighted at Thosum- 4 compartment of NVNP (Management Plan). But this mainly nocturnal animal was not sighted during the recent survey.

Genus: Cuon Hodgson, 1838: Asiatic Wild or Red Dogs

34. Cuon alpinus primaevus Hodgson, 1833: Indian Wild Dog (Mukhopadhyay 1996, Singhal \& Mukhopadhyay 1998; Biswas et al. 1999; Chaudhuri \& Sarkar 2003; Chakraborty et al. 2008b; Dey 2009; UNESCO World Heritage Centre 2009).

O'Malley (1907) reported a good deal of damage to cattle by a pack of Wild Dogs in Lava. Till the end of the $20^{\text {th }}$ century, the Wild Dog was fairly common in NVNP. Almost the entire NVNP, from high altitudes of Rechila on the north to the low altitudes of Sakam on the south, is the recorded movement-zone of this species. Gradual slope and relatively less undergrowth and patches of open areas are their preferred habitats. The Wild Dogs do not occupy any particular area for a long time, but exhibit a great territorial movement covering different altitudes of NVNP and outside. During the winter, most of them are usually confined to the central or southern part, while in the pre- and post-monsoon period they mainly occupy the northern part. Periodical migration of the population of Wild Dogs from NVNP to contiguous parts of Bhutan and Sikkim and vice versa is also reported.

During 1980-2006, 48 sightings and 19 kills of the Wild Dog are recorded in this Park. Considering the frequency of sighting and kill records, Rechila-7, 14, 
15, East Nar-22 and West Nar-3, 10 compartments of NVNP may be regarded as the hot spots for them. The pack size varied from 2-9 individuals. Sighting of the loner is frequent in recent times. The population has, reportedly, declined during the $21^{\text {st }}$ century.

It is mostly a nocturnal hunter. No Wild Dog was seen during the recent survey. But its occurrence was confirmed from the indirect evidences. Tracks were seen and scats were collected at Rechila- 8 $\left(27^{\circ} 03^{\prime} 38.2^{\prime \prime} \mathrm{N} \& 8^{\circ} 45^{\prime} 36.8^{\prime \prime} \mathrm{E}\right)$, East Nar- 22

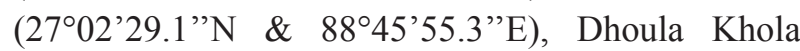
in Rechila- $6\left(27^{\circ} 04^{\prime} 20.1^{\prime \prime} \mathrm{N} \& 8^{\circ} 43^{\prime} 31.5^{\prime \prime} \mathrm{E}\right)$ and Panch Pokhri Khola in West Nar-5 (27'01'31.4"N \& $88^{\circ} 42^{\prime} 51.6$ "E) compartments. The scats were also collected at West Nar- 21 and 23a compartments near Ruka Reserve Forest of KFD. The pugmark of one was plastercast at Rhenock 4b.

Genus: Vulpes Frisch, 1775: Foxes

35. Vulpes vulpes montana Pearson, 1836: Red Fox (Saha et al. 1992; Mukhopadhyay 1996, Singhal \& Mukhopadhyay 1998).

The habitat of the Red Fox includes forest edges, meadows, slopes and the bank of the rivers. Although this nocturnal species was recorded during the $20^{\text {th }}$ century, no evidences of its presence were found during the recent surveys.

Family Felidae Fischer, 1817: Felines/Cats

Subfamily: Felinae Fischer, 1817: Small Cats

Genus: Catopuma Severtzov, 1858: Asiatic Golden Cat and Bay Cat

36. Catopuma temminckii temminckii Vigors and Horsfield, 1827 [on the basis of recent genetic analysis grouped with the Marbled Cat in Pardofelis]: Asian Golden Cat (Anonymous 1964; Biswas \& Ghose 1982; Sharma 1990; Yadav 2004; <http://zsienvis. nic.in/biodiversity_wb/Fauna/43.\%20Mammal.doc> downloaded on 20 October 2009).

The Golden Cat's favourite haunt is the dense forests in the 'terai' and the hills up to an elevation of $1500 \mathrm{~m}$. It takes shelter in the rocks, crevices of boulders and on trees. This nocturnal animal is very rare in the study area. In the past, it was recorded from the Kalimpong Hills, Lish and Ghish areas. Sometimes Golden Cats were reported to stray around Mongpong on the lofty bank of the River Teesta (an ideal breeding place for the migratory birds). Description of a cat, sighted on the eastern bank of River Neora (altitude ca. 305m), about $7 \mathrm{~km}$ south of Samsing, by the villagers in 1982, appeared to be a Golden Cat, which was corroborated by the 'poster-survey'. None was seen or reported during the recent survey.

Genus: Felis Linnaeus, 1758: Pointed-eared Cats

37. Felis chaus affinis Gray, 1830: Jungle Cat or Swamp Lynx (Wroughton 1917b; Anonymous 1964; Sharma 1990; Agrawal et al. 1992; Saha et al. 1992; Mukhopadhyay 1996, Singhal \& Mukhopadhyay 1998; Singhal 1999; Biswas et al. 1999; Prince 2003; Chaudhuri \& Sarkar 2003; Dey 2009).

The Jungle Cat is a common carnivore in the study area and found in the drier and open parts of the forest nearer to grassland and scrubland as well as near the human habitations. N.A. Baptista collected one female at Nimbong and A. Linogreen collected one unsexed individual from Kalimpong in 1938. It is both nocturnal and diurnal in its activities. Sightings took place at upper Rechila Chawk and Jaributi during the recent survey. Footprints were also found there. One Jungle Cat was seen sitting in the middle of the road near the Mahakal trail (Lava) in the early morning.

Genus: Prionailurus Severtzov, 1858: Roundeared Cats.

38. Prionailurus bengalensis horsfieldi Gray, 1842: Leopard Cat (Anonymous 1964; Biswas \& Ghose 1982; Sharma 1990; Saha et al. 1992; Mukhopadhyay 1996, Singhal \& Mukhopadhyay 1998; Biswas et al. 1999; Chaudhuri \& Sarkar 2003; UNESCO World Heritage Centre 2009; <http://westbengalforest.gov.in/ urls_all/ forest_wild_life_animal_2.htm $>$ downloaded on 10 November 2009).

This nocturnal animal is uncommon in the study area and seldom seen. It makes nest in the hollows of large trees. In 1982, it was recorded at Samsing and Rangpo. It was also recorded from Jaributi of NVNP during the recent surveys. Its spoors were also found at East Nar- 19 and Thosum- 1 and 4 compartments.

39. Prionailurus viverrinus viverrinus Bennett, 1833: Fishing Cat (Anonymous 1964; Sharma 1990; Mukhopadhyay 1996, Singhal \& Mukhopadhyay 1998; Biswas et al. 1999; Chaudhuri \& Sarkar 2003; UNESCO World Heritage Centre 2009).

It is a rare nocturnal animal in the study area. During the recent surveys, it was recorded on a number of occasions at Alubari and Jaributi of NVNP, particularly in or near the dense forest, scrub and grass swamps, close to the streams and other water bodies up to the elevations of $1,800 \mathrm{~m}$. Its footprints were also 
found there.

Subfamily: Pantherinae Pocock, 1917

Genus: Neofelis Gray, 1867: Clouded Leopard

40. Neofelis nebulosa macrosceloides Hodgson,

1853: Clouded Leopard (Anonymous 1964; Biswas \& Ghose 1982; Sharma 1990; Saha et al. 1992; Mukhopadhyay 1996, Singhal \& Mukhopadhyay 1998; Singhal 1999; Biswas et al. 1999; Chaudhuri \& Sarkar 2003; Yadav 2004; Chakraborty et al. 2008a; Dey 2009; Rishi 2009; UNESCO World Heritage Centre 2009).

The Clouded Leopard is mainly a nocturnal animal. In 1982, a Clouded Leopard was recorded from Mouchowki (East Nar). But now it is very rare and restricted to a few areas. It was seen at Jaributi and upper NVNP during the current survey. The animal was mainly found in the lower Neora Valley and often outside the Park in the degraded zone near villages. Clouded Leopard was also reported by the villagers of Bhujelgaon at the cardamom plantation near Khasmahal at Mouchowki. Its den was located on the side of a cliff at the junction of Bhujelgaon and Khasmahal. The pugmarks were found near Tempola at East Nar- 22 compartment. A female with cub(s) was earlier sighted in April-May in the evening and at night, but rarely in the morning and afternoon. The animal was also sighted at about $20.00 \mathrm{hrs}$ near Tukre Jhora (stream) of East Nar- 17 compartment. It was recorded at East Nar-19, West Nar-3, 4 and 5 compartments and often in the degraded Khasmahal area beyond the boundary of the Park. It was reported to attack the poultry in the human settlements.

A Clouded Leopard (named Badal) was first reared in captivity at Padmaja Naidu Himalayan Zoological Park (PNHZP), Darjeeling. This male cub was rescued in May 1991 from a dense thicket at the edge of the forest of KFD close to NVNP. Its mother carried away one of the twins in her mouth, leaving the other one behind. But this captive animal ultimately died on 29 March 1993.

Genus: Panthera Oken, 1816: Roaring Cats

41. Panthera pardus fusca Meyer, 1794: Leopard or Panther (Anonymous 1964; Biswas \& Ghose 1982; Sharma 1990; Saha et al. 1992; Mukhopadhyay 1996, Singhal \& Mukhopadhyay 1998; Singhal 1999; Biswas et al. 1999; Chaudhuri \& Sarkar 2003; Wright 2004; Yadav 2004; Chakraborty et al. 2008a; Chakraborty et al. 2008b; Ranganathan et al. 2008; UNESCO
World Heritage Centre 2009; Dey 2009; <http:// westbengalforest.gov.in/urls_all/forest_wild_life_ animal_2.htm> downloaded on 10 November 2009).

The Leopard is a nocturnal big cat and reported to be common in KFD than NVNP. WWF-India, Eastern Region (1997) reported a few incidents of depredation and lifting of goats by leopards in Paparkheti, Algara and Pedong under Lava Range as well as Chotaphagu, Meenglass and Sylee TEs under Chel Range. However, high incidences of depredation were reported in the foothills under Chel Range and at fringe areas of Khumani, Mal basti (village) and Mongpong forest in KFD. The Leopard uses the TEs as nursery on several occasions and cases of killing of cubs by the garden labourers were reported. Cubs were rescued from Phagu, Sylee, Chilauni, Good Hope and Sonagachi TEs and released in the wild. Leopards also died due to poisoning in Targhera and Washabari TEs.

It was earlier recorded from Samsing and Mal areas. There is a sighting record at Chunabhati in KFD during the recent survey. In NVNP, the Leopard was reported from Rechila Chawk. Indirect evidences of its presence like the pugmarks were sighted in Rechila chawk, Alubari, Jaributi, Jorepokhri and Mauchowki areas of NVNP. The scats were also observed along the route from Mauchowki to $7^{\text {th }}$ mile (bordering area of NVNP) and near Thotne point in East Nar-17 compartment at $580 \mathrm{~m}$ and were also collected from Rechila- 13, 14 and Renock- 5 compartments $\left(27.7^{\circ} 0.15 .7^{\prime} .22 .1^{\prime \prime} \mathrm{N} \&\right.$ $\left.88^{\circ} 44^{\prime} 36.1^{\prime \prime} \mathrm{E}\right)$. Its population in KFD was assessed to be only 7 ( $<\mathrm{http}: / /$ westbengalforest.gov.in /urls all/ bio_diversity_census.html $>$ downloaded on 10 November 2009). No population was recorded in NVNP. Scats and pugmarks were, however, found at West Nar 9, 10, 11, 12; Rachila 1, Thosum 1 and East Nar 22 during December 2008.

42. Panthera tigris tigris Linnaeus, 1758: Tiger (Anonymous 1964; Sharma 1990; Saha et al. 1992; Anonymous 1998; Singhal \& Mukhopadhyay 1998; Singhal 1999; Biswas et al. 1999; Yadav 2001, 2004, 2005; Chaudhuri \& Sarkar 2003; Harding 2006; Nandy 2006b; Sanyal 2006; Ranganathan et al. 2008; Anonymous 2009; UNESCO World Heritage Centre 2009; Jha \& Avasthe Undated; <http://www.sikkim. nic.in/sikkimroot/html/wwf3.pdf $>$ downloaded on 5 August 2009; <http://westbengalforest.gov.in/urls_ all/ forest wild life animal 2.htm> downloaded on 10 November 2009; <http://www.telegraphindia. 
com/1081203/jsp/siliguri/story_10199071.jsp> downloaded on 15 October 2009; Mallick 2010c).

The Tiger was earlier recorded from both the plains and higher altitudes of Kalimpong Hills. Roy Harding, in an account of his early school days during 1940s at St. Andrews Colonial Homes (Kalimpong), now known as Dr. Grahams School, wrote:

"Kalimpong is a plateau and reasonably cool the year round. As such, during the hot season in the plains, tigers, usually female, would come up to Kalimpong. I would imagine that they went into the forest north of Laidlaw or beyond for obvious cover. During this time and until the tigers returned to the plains, we were never required to go out to collect firewood. On occasion, usually on a moonlit night, we would be woken from sleep to see a tigress and her cubs leisurely walking past our cottage."

The studies conducted during the 1980s did not mention any resident tiger in NVNP. In fact, before the 1990s, the tiger was an occasional visitor to this Park. Shri P.K. Das, a forest officer, first recorded the tiger pugmarks during a trekking trip in late 1980s. Simultaneously, the entire tiger population (eight numbers recorded last in 1989) was found vanished from Gorumara NP.

Therefore, since the late $20^{\text {th }}$ century, NVNP is recognized as the new retreat of the tiger in northern Bengal. In May 1998, the field staff again traced a few pugmarks. The first tiger census was conducted during November-December and a population of 18 tigers (eight adult females, six adult males, one sub-adult male and three cubs) was recorded in East Nar- 20, 21, 22, 23; Thosum- 1, 2, 3, 4; Rachila- 5, 6, 9, 12, 13, 14, 15, 16, 17 and Rhenok- 2, 4, 5 compartments. Kisor Chaudhuri, while surveying the area under WWF-I, Eastern Region-funded Gaur project in 1997, also confirmed presence of the tiger in NVNP. Movement of the tigers along the river Neora up to an altitude of 2,300m in Rechila Block during February-March was reported. These tigers were also reported to migrate to Sikkim through the forest of Lava during OctoberNovember and follow the same route back to Lava after about three months.

The census figures were recorded as 16 in 2001 and 11 in 2004. During 20-24 November 2008, another Tiger census was conducted and the population was estimated to be 20 in NVNP and 1 in adjoining KFD (<http://westbengalforest. gov.in/urls_all/bio diversity_census.html $>$ downloaded on 10 November 2009). During the present survey, only eight pugmarks could be collected because of difficult terrain and huge accumulation of leaf-litter and six tigers could be identified-one at Rhenock, two at Rechila and three at East Nar. Besides, scats and scratches on tree trunks were also found in these three forest blocks.

A tiger was recently seen in the riverine grassland of Nathua forest under Jalpaiguri FD, which is close to Gorumara NP after almost 20 years and the forest officials reported that the animal might have come from the Neora Valley NP through Chapramari WLS and Bamondanga-Tondu TE. The first hints of this tiger's presence were visible in the last week of March 2008, following reports of cattle lifting from Mouchowki $(1,170 \mathrm{~m})$ in the Bhujelgaon area of the Neora Valley lower range. This area is merely $12 \mathrm{~km}$ from the boundary of Gorumara.

Genus: Pardofelis Severtzov, 1858: Marbled Cat

43. Pardofelis marmorata charltoni Gray, 1846: Marbled Cat (Anonymous 1964; Biswas \& Ghose 1982; Sharma 1990; Saha et al. 1992; Mukhopadhyay 1996, Singhal \& Mukhopadhyay 1998; Chaudhuri \& Sarkar 2003; UNESCO World Heritage Centre 2009)

This nocturnal and arboreal smaller cat is a very rare animal in the study area. In 1982, its occurrence at Mouchowki in NVNP and at higher elevations above Rangpo in KFD was confirmed after questionnaire and poster surveys. It was earlier reported from the dense forests of Jaributi and above. This wild cat was not sighted and the indirect evidences were not found during the recent survey.

Family: Herpestidae Bonaparte, 1845: Mongooses

Subfamily: Herpestinae Bonaparte, 1845: Mongooses

Genus: Herpestes Illiger, 1811: Asiatic mongooses

44. Herpestes edwardsii edwardsii E. Geoffroy Saint-Hilaire, 1818: Indian Grey Mongoose (<http:// www.kolkatabirds.com/netrip1.htm $>$ downloaded on 12 October 2009).

This diurnal species is found in the foothills. It lives in the open areas, scrublands, in and around the cultivated areas. One voucher specimen from the Teesta riverbed is kept at Bengal Natural History Museum (BNHM), Darjeeling. Two individuals were reportedly seen at Suntalekhola. It was not sighted during the recent survey.

45. Herpestes (javanicus)

auropunctatus 
Hodgson, 1836: Small Indian Mongoose [WWF-I (Eastern Region) 1997]

It is a common species in the study area. This is both diurnal and noctural animal. It was not sighted during the recent surveys.

46. Herpestes urva Hodgson, 1836: Crab-eating Mongoose (Anonymous 1964; Sharma 1990; WWF-I Eastern Region 1997)

The Crab-eating Mongoose is diurnal and noctural animal. It is rarely seen. This species was earlier recorded from the hills as well as plains of KFD, particularly near the streams. During the present survey it was not found.

Family: Mustelidae: Mustelids [Weasels, Martens, Badgers, Otters]

Subfamily: Lutrinae Bonaparte, 1838: Otters

Genus: Amblonyx Rafinesque, 1832: Small-clawed otters

47. Amblonyx cinereus (also referred to as Aonyx cinerea) concolor Rafinesque, 1832: Oriental Smallclawed Otter (Saha et al. 1992)

This species prefers wetlands and riverine areas with low vegetation and digs burrows into the muddy banks. It is diurnal and noctural species. But it was not traced during the recent survey.

Genus: Lutra Brünnich, 1771: Common Otters

48. Lutra lutra monticola Hodgson, 1839: Common Indian Hill Otter (Wroughton 1917b; Saha et al. 1992; Chaudhuri \& Sarkar 2003)

During summer, this otter migrates up the streams and torrents ascending to higher altitudes. During winter, it inhabits the lower elevations. It is both diurnal and noctural species. It was once common in the study area and N.A. Baptista collected one female from Pedong, but it was not observed during the recent survey.

Genus: Lutrogale Gray, 1865: Smooth Otters

49. Lutrogale perspicillata perspicillata I. Geoffroy Saint-Hilaire, 1826: Smooth Indian Otter (Saha et al. 1992; Chaudhuri \& Sarkar 2003)

It is both diurnal and noctural species. No direct or indirect evidences of this species were observed during the recent survey.

Subfamily: Melinae Bonaparte, 1838: Old World Badgers (Eurasia)

Genus: Arctonyx Cuvier, 1825: Hog or Sand badgers

50. Arctonyx collaris collaris F. Cuvier, 1825: Hog
Badger (Saha et al. 1992; Chaudhuri \& Sarkar 2003)

During the recent survey, this nocturnal animal was not sighted, but signs of its presence were observed on the Neora riverbed.

Subfamily: Mustelinae Fischer, 1817: Martens, Weasels, Wolverines and relatives

Genus: Martes Pinel, 1792: True Martens

51. Martes flavigula flavigula Boddaert, 1785: Himalayan Yellow-throated Marten or Indian Marten (Wroughton 1917b; Sharma 1990; Saha et al. 1992; Mukhopadhyay 1996, Singhal \& Mukhopadhyay 1998; Biswas et al. 1999; Prince 2003; Chaudhuri \& Sarkar 2003; Chakraborty et al. 2008a)

It keeps to the forest limits and is found at 1219 $2743 \mathrm{~m}$. This marten is both diurnal and nocturnal in activities. It is common in the higher elevations of the study area. N.A. Baptista collected one female from Pedong. This marten was reported earlier from Jaributi, upper Rechila chawk and surrounding areas. Two martens were seen at Lulegaon and Rishyap during the recent survey. One was also reported at West Nar 11, 12 during December 2008. Scats were also collected at Rechila-12 compartment $\left(27^{\circ} 07^{\prime} 0.6^{\prime \prime} \mathrm{N} \&\right.$ 88043'12.6”'E).

52. Martes foina intermedia Severtzov, 1873: Beech Marten or Stone Marten (Sharma 1990; Agrawal et al. 1992; Mukhopadhyay 1996, Singhal \& Mukhopadhyay 1998; Biswas et al. 1999; Chaudhuri \& Sarkar 2003).

This marten is found in the rocky parts of the hill forest and on the barren heights above the treeline. It takes shelter in the hollows of trees, underlogs, among the rocks and in ground burrows. Though recorded to be common, this marten was only once observed below $1,214 \mathrm{~m}$ in NVNP, while feeding on a young Barking Deer (Ghose 1985). It was also sighted at Jaributi and upper Rechila chawk during the recent survey.

Genus: Mustela Linnaeus, 1758: True Weasels

53. Mustela altaica temon Hodgson, 1857: Alpine Pale Weasel (Saha et al. 1992)

This weasel is active during both the day and night. In Bhutan, it is confined to 1,500-5,200 m altitude (Abramov et al. 2008). Though it was recorded at NVNP in the past, no evidences of this species were found during the recent survey.

54. Mustela kathiah kathiah Hodgson, 1835: Yellow-bellied Weasel (Chakraborty et al. 2008b)

It is found in the dense forests, dry sandy valleys 
and even low-lying swamps. It prefers the alpine forests. It is a common weasel in the hills and was sighted in NVNP during the recent survey.

55. Mustela strigidorsa Gray, 1855 (subspecies none): Siberian Stripe-backed Weasel (Mukhopadhyay 1996, Singhal \& Mukhopadhyay 1998; Biswas et al. 1999).

It is found in the temperate forest, open grassland and scrub jungles of upper Rechila chawk area. It is very rare in the study area and no evidences of this species were found during the current survey.

Family: Ailuropodidae: Pandas

Subfamily: Ailurinae: Panda bears

Genus: Ailurus F. Cuvier, 1825: Lesser panda

56. Ailurus fulgens fulgens $\mathrm{F}$. Cuvier, 1825: Red Panda or Cat Bear (Biswas \& Ghose 1982; Tikader 1983; Sharma 1990; Agrawal et al. 1992; Saha et al. 1992; Mukhopadhyay 1996, Singhal \& Mukhopadhyay 1998; Singhal 1999; Choudhury 2001; Prince 2003; Chaudhuri \& Sarkar 2003; Wright 2004; Ghose et al. 2007; Anonymous 2008; UNESCO World Heritage Centre 2009; <http://westbengalforest.gov.in/urls_all/ forest wild life animal 2.htm $>$ downloaded on 10 November 2009; Mallick 2010b).

The Red Panda is a focal species for conservation in the Himalayan temperate forests and an umbrella species for the sub-alpine forests. The undisturbed forest of NVNP is the last remaining good habitat for the Red Panda. It occurs sporadically in NVNP (Tikader 1983; Saha \& Singhal 1996). It is found in the high forests, particularly the deciduous and coniferous types, usually with an under-storey of bamboo above $1,524 \mathrm{~m}$. During the recent surveys, the higher elevation of temperate zone, namely Raschet, Rechila and Thosum, is found to be the abode of this species. Earlier, it was recorded from Mouchowki. It was also reported from Pankasari in KFD. But its sighting is very rare in the study area.

In March 2000, a sick Red Panda was rescued from NVNP. But it died on the way to PNHZP. An adult male was found dead at Pankhasari-1 compartment (Lava Range, KFD) on 11 May 2008. Presence of the Red Pandas in NVNP was confirmed in WWF-I, Eastern Region-funded survey report. From the evidences gathered during the first systematic survey of the Red Panda in NVNP [Ashoka Trust for Research in Ecology and Environment (ATREE) team in 2006 (Anon 2008)], 28-32 Red Pandas were estimated for the upper NVNP. Photograph of one was taken at Rhenock $4 \mathrm{~b}$ and another was sighted at Rechila-2 in December 2008. It was also reported that in 2009 eleven sightings were recorded in five out of 25 compartments of NVNP (particularly Rashet- 3,4; Rechila- 11, 12 and Rhenock- 4b) within 2,350-3,170 m.

Family: Ursidae Fischer, 1817: Bears

Subfamily: Ursinae Fischer, 1817: Bears

Genus: Melursus Meyer, 1793: Sloth bears

57. Melursus ursinus ursinus Shaw, 1791: Sloth Bear (Sharma 1990; Saha et al. 1992; Chaudhuri \& Sarkar 2003; Yadav 2004).

In the late $19^{\text {th }}$ and early $20^{\text {th }}$ century, the Sloth Bear was common in the foothills. Now, it is a rare species due to destruction of the habitat and poaching. Earlier, it was reported from Samsing and Mouchowki. Its pugmarks were also seen there. No evidences of this nocturnal species were found during the recent field survey.

Genus: Ursus Linnaeus, 1758: Asiatic Black Bears.

58. Ursus (Selenarctos) thibetanus laniger Pocock, 1932: Asiatic or Himalayan Black Bear (Biswas \& Ghose 1982; Ghose 1985; Sharma 1990; Agrawal et al. 1992; Saha et al. 1992; Mukhopadhyay 1996, Raha 1996; Singhal \& Mukhopadhyay 1998; Biswas et al. 1999; Servheen et al. 1999; Singhal 1999; Sathyakumar 2001; Chaudhuri \& Sarkar 2003; Wright 2004; Yadav 2004; Chakraborty et al. 2008a; Chakraborty et al. 2008b; UNESCO World Heritage Centre 2009; <http://westbengalforest.gov.in/urls_all/ forest_wild_life_animal_3.htm $>$ downloaded on 10 November 2009).

It is a nocturnal species. The survey conducted by Kisor Chaudhuri (WWF-I, Eastern Region) confirmed presence of this species in NVNP. This bear was earlier seen at Mouchowki. It is recorded as common in NVNP. It was sighted and feeding evidences were found at East Nar- 18, 21, 23a; Thosum- 1, 4; and Rechila- 7, 11, 12 compartments during the recent survey. Its obliterated tracks were also observed at Jorepokhari. Scats were collected at Rechila- 13 compartments $\left(27^{\circ} 07^{\prime} 37.5^{\prime \prime} \mathrm{N}\right.$ \& 88.43'37.5'E). The population in NVNP was estimated to be 18 (<http://westbengalforest.gov.in/ urls_all/ bio_diversity_census.html $>$ downloaded on 10 November 2009).

In the summer, it inhabits in deciduous and mixed 
forests at the higher altitudes and in the winter it decends to the lower hills and valleys even down to about $1,524 \mathrm{~m}$. During the summer, they are commonly sighted at Lava areas. Mostly the solitaries were sighted. It was encountered at Mouchowki. Quite often the villagers are mauled on sudden encounters when they enter the forest to collect fodders and fuelwood. The villagers are, therefore, scared of the Himalayan Black Bear. These bears are reported to cause damage to the maize crop and livestock in the fringe villages like Mulkharg, Kolbong and Lingasay. In 1995, two cubs were rescued from the medicinal flora farm at Khumani Village. The Himalayan Black Bear is often poached for its bile. In Darjeeling and Kalimpong areas 30 to 40 percent bears are killed while hibernating inside the hollow of the trees, for illegal trade (Subba 2000).

Family: Viverridae Gray, 1821: Civets

Subfamily: Paradoxurinae Gray, 1821: Binturong and Palm Civets

Genus: Paguma Gray, 1831: Masked Palm Civet

59. Paguma larvata neglecta Pocock, 1934: Himalayan or Masked Palm Civet (Saha et al. 1992; Mukhopadhyay 1996, Singhal \& Mukhopadhyay 1998; WWF-I Eastern Region 1997; Biswas et al. 1999; Chaudhuri \& Sarkar 2003).

Masked Palm Civets are confined to the fragmented areas in both evergreen and deciduous forests in the mountains and hills. It takes shelter in the holes of trees. This nocturnal animal is reported to be rare in NVNP. Earlier, it was reported from Rechila chawk and surrounding forests. It was not sighted or reported during the recent survey.

Genus: Paradoxurus F. Cuvier, 1821: Palm Civets

60. Paradoxurus hermaphroditus bondar

Desmarest, 1820: Toddy Cat or Common Palm Civet (Biswas \& Ghose 1982; Saha et al. 1992; Mukhopadhyay 1996, WWF-I Eastern Region 1997; Singhal \& Mukhopadhyay 1998; Biswas et al. 1999; Chaudhuri \& Sarkar 2003).

It is a nocturnal animal and commonly found near the human habitations. Earlier, it was recorded from Samsing, Rechila Chawk and surrounding forests. But it was not sighted during the recent survey.

Genus: Prionodon Horsfield, 1822: Banded or Spotted Linsang or Tiger Civet

61. Prionodon pardicolor pardicolor Hodgson, 1842: Tiger Civet or Spotted Linsang (Sharma 1990)
It is found in the tropical and subtropical forests up to the elevations of $2,100 \mathrm{~m}$, but very rare. This nocturnal species was recorded earlier in the study area but not sighted or reported during the recent survey.

Subfamily: Viverrinae Gray, 1821: Civets, Genets and Linsangs

Genus: Viverra Linnaeus, 1758: Civets

62. Viverra zibetha zibetha Linnaeus, 1758: Large Indian Civet (Wroughton 1917b; Sharma 1990; Saha et al. 1992; WWF-I Eastern Region 1997; Singhal 1999; Chaudhuri \& Sarkar 2003).

It is a solitary animal living in the woods under bushes or in the heavy scrub jungle. This nocturnal species was common in the study area in the past. N.A. Baptista collected one female and one male from Nimbong. Its population is reportedly declined. Though not sighted, its scats were found at Rechila13 compartment during the recent survey.

Genus: Viverricula Hodgson, 1838: Small Indian civets

63. Viverricula indica baptistae Pocock, 1933: Small Indian Civet (Saha et al. 1992; WWF-I Eastern Region 1997; Chaudhuri \& Sarkar 2003)

The Small Indian Civet is found at the edges of the lower-lying forest in long grass or scrub jungle at altitudes up to $1,200 \mathrm{~m}$. Though this nocturnal species was recorded earlier in the study area, it was not seen during the current survey.

Order Proboscidae Illiger, 1811: Elephants

Family: Elephantidae Gray, 1821: Elephants

Genus: Elephas Linnaeus, 1758: Asian elephant

64. Elephas maximus indicus F. Cuvier, 1798: Indian Elephant (Anonymous 1964; Sharma 1990; Dey 1991a, 1991b; Saha et al. 1992; Raha 1996; Chaudhuri \& Sarkar 2003; Yadav 2004; Nanjappa 2008; UNESCO World Heritage Centre 2009; <http:// elephantsindia.blogspot.com $>$ downloaded on 10 July 2009; <http://www.indiaenews.com/pdf/77036.pdf > downloaded on 10 July 2009).

Prior to 1950 's, the elephant population existed in small herds in scattered manner, particularly in the wet-mixed forests of KFD. Two herds were confined to the Kalimpong hills (O’Malley 1907):

"One herd of wild elephants from the Tondu forest in Jalpaiguri usually goes as far as the Naksal Khar, a large salt lick on a tributary of the River Jaldhaka to the east of the Kalimpong hills, but they also go further into the hills reaching Rishi-la $(3,200 \mathrm{~m})$, 
the highest peak of the Chola range, situated on the Sikkim and Bhutan border, and even roam about in the snow at that height. Another herd, about 20 in number, works fairly constantly between the Rivers Teesta and Jaldhaka, their headquarters being the Mal and East Nar forest blocks, though they also ascend the hills and graze in the higher tracts adjoining Bhutan." But since the Second World War, they suspended their visits to these areas.

In NVNP, Hathi Danda (peak) at about $3,000 \mathrm{~m}$ was an elephant route till 1940 (Anonymous 2010). Prior to 1977, the elephants moved from the Titi reserve forest of Jaldapara WLS in the east (west of the River Torsa) to KFD in the west in June-July and returned in November-December. Now, these animals are occasionally seen in the 'terai'. The solitaries are reported to stray and invade the valley up to an altitude of about $914 \mathrm{~m}$, mostly during the crop-harvesting season on the hill slopes of Sakkam, Gorubathan, Targhera and adjoining areas. They also visit the lower reaches of the valley in lure of the wild banana.

Elephant depredation in the fringe areas, including TEs, of Gorubathan, Tashiding, Mongpong, Targhera, etc. is often reported. On 24 November 2008, one forest guard was injured by a member of a herd of 50 elephants in the Targhera forests. A few elephants also died due to road and train accidents, electrocution and poaching.

Order: Artiodactyla Owen, 1848: Even-toed ungulates or hoofed mammals

Family: Suidae Gray, 1821: Pigs

Subfamily: Suinae Gray, 1821: Hogs and Pigs

Genus: Sus Linnaeus, 1758: Pigs

65. Sus scrofa cristatus Wagner, 1839: Indian Wild Boar (Biswas \& Ghose 1982; Sharma 1990; Mukhopadhyay 1996, WWF-I Eastern Region 1997; Singhal \& Mukhopadhyay 1998; Biswas et al. 1999; Singhal 1999; Chaudhuri \& Sarkar 2003; Bahuguna \& Mallick 2004; Chakraborty et al. 2008b; Dey 2009).

The Wild Boar is found in plenty in the study area. It is both nocturnal and diurnal in their activities. Earlier, it was recorded from Samsing, Rangpo and Tarkhola under KFD and Rechila Chawk and Jaributi under NVNP. Soil-excavations by this animal were also seen. In NVNP, the Wild Boars were sighted, their calls heard and tracks (about $5 \mathrm{~cm}$ ) found at East Nar22, 23a, 21; Thosum- 1, 2, 3, 4 and Rachila- 5, 10, 11, 12 compartments during the recent survey. Tracks with distinctive imprint of 2 "dew" claws were also noticed in plenty on the wet sandy patches in and around the River Neora, Ashalary khola, Sakam khola, Dhoula khola, etc. The fresh, dark brown scats, much larger and bulkier than the deer pellets, containing remains of the larger plant stems and roots, were also seen. Reportedly, the Wild Boars often raid the village crops and cause depredation. The estimated populations of 615 and 110 were recorded in NVNP and KFD respectively $(<\mathrm{http}: / /$ westbengalforest.gov. in/urls_all/bio_diversity_census.html $>$ downloaded on 10 November 2009).

Family: Cervidae Goldfuss, 1820: Deer

Subfamily: Cervinae Goldfuss, 1820: Old World (Plesiometacarpal) Deer

Genus: Axis H. Smith, 1827: Axis deer

66. Axis axis axis Erxleben, 1777: Spotted Deer or Cheetal (Ghosh 1997; WWF-I Eastern Region 1997; Singhal 1999; Bahuguna \& Mallick 2004)

The terai forest was the habitat of the Spotted Deer in the study area. There are no current sighting records of this species. It seems to be locally extinct. Small population is, however, found in the pockets of the adjoining Baikunthapur forests resuscitated recently.

Genus: Rucervus Hodgson, 1838: Deer

67. Rucervus duvauceli duvaucelii Cuvier, 1823: Swamp Deer or Barasinga (Anonymous 1964)

It was once common in the 'terai' forests of Kalimpong, but disappeared from the study area sometimes during early $20^{\text {th }}$ century.

Genus: Rusa C.H. Smith, 1827: Sambar and Rusa Deer

68. Rusa unicolor niger Blainville, 1816: Sambar (Anonymous 1964; Biswas \& Ghose 1982; Sharma 1990; Ghosh 1997; Singhal 1999; Chaudhuri \& Sarkar 2003; Bahuguna \& Mallick 2004; UNESCO World Heritage Centre 2009).

The Sambar is common in NVNP and found up to the elevations of $914-1,372 \mathrm{~m}$. It is mainly a night forager. Earlier, it was recorded from Samsing. In KFD, this species was seen in the Lish, Churanthi and Ramthi blocks of Chel Range and from the Teesta Bridge to the Coronation Bridge of Kalimpong Range. Hoof-marks of the Sambar were found at East Nar22, 23a; Thosum- 1 and Rachila- 7 compartments during the recent surveys. Its population in NVNP was estimated to be 286 (<http://westbengalforest.gov.in/ urls_all/bio_diversity_census.html $>$ downloaded on 
10 November 2009).

Subfamily: Muntiacinae Pocock, 1923: Muntjacs

Genus: Muntiacus Rafinesque, 1815: Southern Red

\section{Muntjac or Indian Muntjac}

69. Muntiacus vaginalis Boddaert, 1785 [Groves (2003) elected to raise non-Sundaic forms of $M$. muntjak from subspecific taxa to the species $M$. vaginalis]: Barking Deer (Anonymous 1964; Biswas \& Ghose 1982; Sharma 1990; Mukhopadhyay 1996, Ghosh 1997; WWF-I Eastern Region 1997; Singhal \& Mukhopadhyay 1998; Biswas et al. 1999; Singhal 1999; Chaudhuri \& Sarkar 2003; Chakraborty et al. 2008a; Chakraborty et al. 2008b; Dey 2009; UNESCO World Heritage Centre 2009; <http://www.kolkatabirds.com/ netrip1.htm $>$ downloaded on 12 October 2009)

The Barking Deer is abundant in the study area. Earlier, it was recorded from Samsing, Mouchowki, Rangpo and Tarkhola. In KFD, this deer is seen from the foothills to an altitude of $2,340 \mathrm{~m}$ in the upper hills. Solitary Barking Deer was frequently met with and the alarm calls were often heard in the evening in NVNP. The animal was sighted and its pellets and hoof marks were found at East Nar- 22, 23a, West Nar- 9, Thosum- 1 and Rachila- 7 compartments as well as the Gorubathan forests during the recent survey. The foot markings were also observed near Tempola (an open waterbody) at an altitude of $2,058 \mathrm{~m}\left(27^{\circ} 02^{\prime} 58.9^{\prime \prime} \mathrm{N} \&\right.$ $\left.88^{\circ} 46^{\prime} 33.4^{\prime \prime} \mathrm{E}\right)$, Mithun Khar (a natural saltlick) in East Nar-19 compartment $\left(27^{\circ} 01^{\prime} 45.5^{\prime}\right.$ 'N \& 88 $88^{\circ} 46.9^{\prime \prime} \mathrm{E}$ long, altitude 790m) and PHE camp (altitude 1,900m). A pair was also sighted at Choudapheri. A sub-adult male was found dead on 28 November 2006 at Lower Neora range. Its population was estimated to be 590 in NVNP and 57 in KFD ( $<$ http://westbengalforest.gov. in/urls_all/bio_diversity_census.html $>$ downloaded on 10 November 2009).

Family: Bovidae Gray, 1821: Bovids (Antelopes, Cattle, Gazelles, Goats, Sheep and relatives)

Subfamily: Bovinae Gray, 1821: Bison, Buffalos, Cattle and relatives

Genus: Bos Linnaeus, 1758: Oxen and True Cattle

70. Bos gaurus gaurus C.H. Smith, 1827: Gaur (Anonymous 1964; Sharma 1990; Saha et al. 1992; Mukhopadhyay 1996; Bhattacharya et al. 1997; Ghosh 1997; Singhal \& Mukhopadhyay 1998; Biswas et al. 1999; Singhal 1999; Choudhury 2002; Chaudhuri \& Sarkar 2003; Yadav 2004; Bahuguna \& Mallick 2004; Chakraborty et al. 2008b; UNESCO World Heritage
Centre 2009; Dey 2009; <http://westbengalforest. gov.in/urls_all/forest wild life animal 3.htm $>$ down loaded on 10 November 2009).

The Gaurs are not permanent residents in the study area but usually found visiting the plains and 'terai'. In $\mathrm{KFD}$, it is found in the middle and upper hills forests, particularly in the eastern portion. The migratory herds of Gaur were occasionally seen in NVNP. Earlier three herds were located in Mo, Thosum and Rechila blocks and seen to climb up very fast on the steep terrains up to $2,590 \mathrm{~m}$ or above. Its indirect evidences [foot prints, feeding signs and dung] were found at East Nar- 19, 21, 22, 23a; Thosum- 1, 2, 3, 4 and Rechila- 5, 7, 16 compartments during the recent survey. As per the monitoring reports, the herds of Gaur often visit the muddy areas adjacent to Tempola and Jorepokhari wetlands in NVNP. The census figure for NVNP was 81 (<http://westbengalforest.gov.in/ urls all/bio_diversity census.htm $>$ downloaded on 10 November 2009).

The main range of Gaur is in the GorumaraChapramari-Diana forests in Jalpaiguri district. But, in the summer, when the temperature soars in the plains, the small splinter groups of Gaur (mostly bulls) often move further north up to the temperate NVNP through the riverbeds, then descend to Gorubathan and thereafter march towards the Apalchand forests of Baikunthapur FD in the west and go back to their original habitat. It was reported from Thosum area of NVNP during the present survey. The marauding adult bulls, which stray from the reserve forests to the adjacent TEs and human settlements, are often driven back by the wildlife squads, but sometimes the straying Gaurs died due to the capture myopathy and poaching.

Subfamily: Caprinae Gray, 1821: Chamois, Goats, Serows, Sheep and relatives

Genus: Hemitragus Hodgson, 1841: Tahrs

71. Hemitragus jemlahicus schaeferi Pohle, 1944: Himalayan Tahr (Tikader 1983; Ghose 1985; Sharma 1990; Agrawal et al. 1992; Mukhopadhyay 1996, Singhal \& Mukhopadhyay 1998; Singhal 1999; Biswas et al. 1999; Chaudhuri \& Sarkar 2003; Yadav 2004; Chakraborty et al. 2008b; UNESCO World Heritage Centre 2009).

This diurnal species is found in the inaccessible terrain, towering the cliffs, rocks, dense forest and scrub jungle at elevations from $914-2,743 \mathrm{~m}$. The 
survey party of ZSI encountered small flocks in NVNP during early 1980s. It was reported from Rechila, Jorepokhri and Triangular point during the recent survey. Footprints and faecal pellets were also found at Thosum-1 and Rechila-7 compartments. The population in NVNP was estimated to be $32(<\mathrm{http}: / /$ westbengalforest.gov.in/urls_all/bio_diversity_ census.html $>$ downloaded on 10 November 2009).

Genus: Naemorhedus Smith, 1827: Gorals

72. Naemorhedus goral hodgsoni Pocock, 1908: Brown Goral (Anonymous 1964; Sharma 1990; Saha et al. 1992; Mukhopadhyay 1996, Singhal \& Mukhopadhyay 1998; Singhal 1999; Chaudhuri \& Sarkar 2003; Yadav 2004; Chakraborty et al. 2008; UNESCO World Heritage Centre 2009; Dey 2009).

Gorals live on the rugged hillsides and on rocky grounds near the coniferous forest zone. They usually prefer the grassy patches of the middle slopes, migrating from the higher altitudes to the lower altitudes in winter and vice versa in summer. They are both diurnal and nocturnal in their activities. This species was reported from the north-eastern part of Rechila chawk. During the recent survey, this species was sighted at East Nar-19 compartment in NVNP. Pellets and hoof marks were also found there. The estimated population was 73 in NVNP and only three in KFD $(<\mathrm{http}: / /$ westbengalforest. gov.in/urls_all/bio diversity_census.html $>$ downloaded on 10 November 2009).

Genus: Capricornis Ogilby, 1836: Serows

73. Capricornis (Naemorhedus) sumatraensis jamrachi Pocock, 1908: Mainland Serow (Ellerman \& Morrison-Scott 1951; Anonymous 1964; Sharma 1990; Agrawal et al. 1992; Singhal \& Mukhopadhyay 1998; Singhal 1999; Chaudhuri \& Sarkar 2003; Yadav 2004; Anonymous 2008; Dey 2009; UNESCO World Heritage Centre 2009; <http://westbengalforest.gov.in/ urls_all/ forest_wild_life_animal_3.htm $>$ downloaded on 10 November 2009).

The Serow inhabits the steep ridges and precipice at elevations ranging from 1,828-3,048 $\mathrm{m}$. Its type locality is Kalimpong (Pocock 1908). But sighting of this nocturnal mammal is very rare. An ATREE team recorded and photographed this species recently in NVNP. One Serow was sighted at Rachila-2a during December 2008 and hoof marks of this animal were found at Rechila-16 compartment during the recent survey. Carcass of a Serow, the internal parts of which were removed, was seized from a poacher at Rachila on 16 October 2008. Its population in NVNP was estimated to be 89 ( $<\mathrm{http}: / /$ westbengalforest.gov.in/ urls_all/bio_diversity_census.html $>$ downloaded on 10 November 2009).

Order: Pholidota Weber, 1904: Pangolins

Family: Manidae Gray, 1821: Pangolins

Genus: Manis Linnaeus, 1758: Pangolins or Scaly Ant-eaters

74. Manis crassicaudata Gray, 1827: Scaly Anteater or Indian Pangolin (Anonymous 1964; Sharma 1990; Saha et al. 1992; Singhal \& Mukhopadhyay 1998; Chaudhuri \& Sarkar 2003; UNESCO World Heritage Centre 2009).

The Indian Pangolin is found in the plains and lower slopes, living inside hollowed trees or burrows. Records of the sighting and indirect evidences of this nocturnal animal were not available during the recent survey. Its population has greatly reduced due to killing for the flesh and scales.

75. Manis pentadactyla aurita Hodgson, 1836: Chinese Pangolin (UNESCO World Heritage Centre 2009)

The Chinese Pangolin is found in the undisturbed hill forests and grasslands. On 3 April 2008, a carcass was seized from the Piok basti (village) of Kalimpong. The sighting and indirect evidences of this nocturnal species were not recorded during the recent survey.

Order: Rodentia Bowdich, 1821: Rodents

Suborder: Sciurognathi Brandt, 1855: Gophers, Mice, Rats, Squirrels and relatives

Family: Sciuridae Hemprich, 1820: Squirrels

Genus: Callosciurus Gray, 1867: Beautiful Squirrels

76. Callosciurus pygerythrus lokroids Hodgson, 1836: Hoary-bellied Himalayan (Irrawady) Squirrel (Wroughton 1917b; Biswas \& Ghose 1982; Sharma 1990; Agrawal et al. 1992; Mukhopadhyay 1996, Singhal \& Mukhopadhyay 1998; Biswas et al. 1999; Chaudhuri \& Sarkar 2003; Chakraborty et al. 2008b; Dey 2009; <http://www.kolkatabirds.com/netrip1. $\mathrm{htm}>$ downloaded on 12 October $2009 ;<\mathrm{http}: / /$ zsienvis. nic.in/biodiversity_wb/Fauna/43.\%20Mammal.doc $>$ downloaded on 20 October 2009)

This diurnal forest squirrel is found in the temperate and subtropical evergreen and dry deciduous montane forests, particularly the mid-canopy with thick to moderate evergreen forest patches. It is common at 
the lower elevations ranging from $500-1,560 \mathrm{~m}$ in the study area. It was earlier reported from Samsing, Rangpo and Tarkhola. N.A. Baptista collected two females from Sangser and one male from Nimbong. R.L. Fernandez collected one male and three females from Tarkhola in 1958. R.L. Chowdhury collected one male, one female and one unsexed squirrel from Samsing in 1980. It was sighted from Rashet and Lava during the recent survey.

Genus: Dremomys Heude, 1898: Asian Montane Ground Squirrels

77. Dremomys lokriah lokriah Hodgson, 1836: Orange-bellied Himalayan Squirrel (Sharma 1990; Mukhopadhyay 1996, Singhal \& Mukhopadhyay 1998; Biswas et al. 1999; Chaudhuri \& Sarkar 2003; Chakraborty et al. 2008b; Dey 2009; <http://www. birdtours.co.uk/tripreports/india/india11/list.htm> downloaded on 6 September 2009)

This diurnal squirrel usually lives in the subtropical montane evergreen and broad-leaved forests, particularly the tree hollows in mid-high canopy of dense oak, bamboo, fir and pine forest patches at altitudes ranging from $900-2,743 \mathrm{~m}$. It is common in NVNP. It seldom gives vent to a loud crackling call. During the recent survey, this arboreal squirrel was sighted at Lava, Damdama danda, Thosum and Rechila.

Genus: Ratufa Gray, 1867: Asian Giant Squirrels

78. Ratufa bicolor gigantea Sparrman, 1778: Large Indian (Malayan/Assam) Black Giant Squirrel (Wroughton 1917b; Anonymous 1964; Biswas \& Ghose 1982; Sharma 1990; Agrawal et al. 1992; Saha et al. 1992; Mukhopadhyay 1996, WWF-I Eastern Region 1997; Singhal \& Mukhopadhyay 1998; Biswas et al. 1999; Chaudhuri \& Sarkar 2003; Dey 2009; UNESCO World Heritage Centre 2009; ; $<$ http://zsienvis.nic.in/biodiversity_wb/Fauna/43.\%20 Mammal.doc $>$ downloaded on 20 October 2009).

This diurnal giant squirrel is found in the tropical and subtropical montane evergreen and dry deciduous forests, particularly the tree hollows in mid-high canopy. It does not usually come to the ground. N.A. Baptista collected two males and one female from Sangser. One male and two females were also collected from Tarkhola by H. Khajuria in 1958. Once it was common in the study area, but due to anthropogenic pressure and consequent decline in the population, it has now become rare. A few squirrels were earlier recorded from Samsing, Rangpo and Mouchowki. This species was seen in small numbers at Lava, Samsing and Jaributi valley during the recent survey.

Genus: Tamiops J.A. Allen, 1906: Asian Striped Squirrels

79. Tamiops macclellandi macclellandi Horsfield, 1840: Himalayan Striped Squirrel $(<\mathrm{http} / / / \mathrm{www}$. birdtours.co.uk/tripreports/india/india11/list.htm>. Downloaded on 6 September 2009; http://www. kolkatabirds.com/netrip1.htm> downloaded on 12 October 2009).

This diurnal striped squirrel lives inside the treehollows in montane region up to $1,500 \mathrm{~m}$. During the recent survey, a few squirrels were seen in Lava, particularly along the Tiffindara trail.

Family: Pteromyidae Brandt, 1855: Flying Squirrels

Subfamily: Petauristinae Miller, 1912: Flying Squirrels

Genus: Belomys Thomas, 1908: Hairy-footed Flying Squirrels

80. Belomys pearsonii pearsonii Gray, 1842: Hairy-footed Flying Squirrel (Ghose, 1985; Sharma 1990; Agrawal et al. 1992; Saha et al. 1992; Chaudhuri \& Sarkar 2003).

This small flying squirrel lives in the tree-hollows of dense broad-leaved forest patches and also in rock crevices at 1,500-2,400 m altitude. It is reportedly common in the study area. A ZSI team observed this squirrel earlier at NVNP. But this nocturnal squirrel was not sighted during the recent survey.

Genus: Hylopetes Thomas, 1908: Pygmy Flying Squirrels

81. Hylopetes alboniger alboniger Hodgson, 1836: Particolored Flying Squirrel (Sharma 1990; Saha et al. 1992; Mukhopadhyay 1996, Singhal \& Mukhopadhyay 1998; Biswas et al. 1999; Chaudhuri \& Sarkar 2003; <http://www.kolkatabirds.com/netrip1. $\mathrm{htm}>$ downloaded on 12 October 2009).

This nocturnal species lives in the tree-hollows of the montane forests up to about $1,524 \mathrm{~m}$. Its sighting was reported in Rhenok earlier. It is rare in the study area. However, one was seen at Rashet during the recent survey.

Genus: Petaurista Link, 1795: Large Asiatic Flying Squirrels

82. Petaurista elegans caniceps Gray, $1842[P$. caniceps is also treated as a distinct species in Corbet 
\& Hill (1992)]: Lesser or Spotted Giant Grey-headed Flying Squirrel (Sharma 1990; Saha et al. 1992; Chaudhuri \& Sarkar 2003).

This large flying squirrel is generally found on the tall trees, nesting in the tree-hollows, but also often seen in the rhododendron scrub and on the rock cliffs at high altitude. It is a nocturnal flying squirrel and was not sighted during the recent survey. The indirect evidences of its presence were also not found.

83. Petaurista magnificus hodgsoni Ghose and Saha, 1981: Hodgson's Common Giant Flying Squirrel (Biswas \& Ghose 1982; Saha et al. 1992; Singhal 1999; Chaudhuri \& Sarkar 2003; Alfred et al. 2006; Chakraborty et al. 2008a; Dey 2009).

This nocturnal species prefers the dry deciduous to evergreen forests at higher altitudes $(1,828-2,743$ $\mathrm{m})$. It usually roosts in a tree-hole, emerges from this shelter at dusk and retires before dawn. It was earlier recorded from Tarkhola of KFD. This large flying squirrel was often seen in NVNP, leaping up to 6-7 $\mathrm{m}$ from one tree to another, during the recent survey. Two dead juveniles were also found at East Nar- 23a compartment and near Suntalekhola.

84. Petaurista nobilis singhei Saha, 1977: Himalayan Flying Squirrel (Anonymous 1964; Sharma 1990)

The Himalayan Flying Squirrel is found in the pine and rhododendron forests, flying from one tree to another. It is common in NVNP and also recorded in KFD. But this nocturnal squirrel was not sighted during the recent surveys.

85. Petaurista petaurista Pallas, 1766: Elliot's Common Red Giant Flying Squirrel (Sharma 1990; Saha et al. 1992; Chaudhuri \& Sarkar 2003)

This species is found in the moist evergreen forests from 500-3,100 m. It lives in the hollows of old trees, often within the villages. Though earlier recorded in NVNP, this nocturnal large flying squirrel was not found during the recent surveys.

Family: Cricetidae J. Fischer, 1817

Subfamily: Arvicolinae Gray, 1821: Arvicoline Rodents

Genus: Neodon Lataste, 1887: Meadow Mice, Meadow Voles

86. Neodon (Microtus) sikimensis sikimensis Hodgson, 1849: Sikkim Vole (Sharma 1990; Mukhopadhyay 1996, Singhal \& Mukhopadhyay 1998; Biswas et al. 1999; Chaudhuri \& Sarkar 2003)
Sikkim Vole is found above $2,100 \mathrm{~m}$ altitude in the forest floor, under the rocks, bushes, leaf litter and outskirts of the rhododendron and coniferous forests, alpine meadow, shrub-lands and grasslands. It lives in the hollows of trees. It is mainly diurnal. At the dusk, it was sighted at Rechila chawk during the recent survey. However, it is rare in NVNP.

Family: Muridae Illiger, 1815: Old World Rats and Mice

Subfamily: Murinae Illiger, 1811: Old World Rats and Mice

Genus: Bandicota Gray, 1873: Bandicoot Rats

87. Bandicota bengalensis bengalensis Gray and Hardwicke, 1833: Lesser Bandicoot Rat (Wroughton, 1917b; Agrawal et al. 1992; <http://zsienvis.nic. in/biodiversity_wb/Fauna/43.\%20Mammal.doc $>$ downloaded on 20 October 2009).

It is the dominant rodent species in the study area, mostly found in the vicinity of the human settlements. N.A. Baptista collected one male and six females from Kalimpong and five males and nine females from Nimbong. This nocturnal rat was sighted during the recent surveys.

Genus: Mus Linnaeus, 1758: Mouses

88a. Mus musculus homourus Hodgson, 1845: House Mouse (Wroughton, 1917b; Agrawal et al. 1992; <http://zsienvis.nic.in/biodiversity_wb/ Fauna/ 43.\% 20 Mammal.doc> downloaded on 20 October 2009).

It is very common in the study area and was collected mostly from the houses and occasionally from the fields in the foothills. N.A. Baptista collected six males and two females from Kalimpong, two males and one female from Nimbong, 12 males and 14 females from Pedong and one male and one female from Sangser. H. Khajuria also collected one male and four females from Tarkhola in 1958. This nocturnal mouse was sighted during the current survey in NVNP.

88b. Mus musculus urbanus Hodgson, 1845: House Mouse (Wroughton, 1917b; Agrawal et al. 1992; <http://zsienvis.nic.in/biodiversity_wb/Fauna/ 43.\% 20 Mammal.doc $>$ downloaded on 20 October 2009).

It is most common in and around the human habitations in the foothills. N.A. Baptista collected three males and three females from Kalimpong. It was sighted during the current surveys in NVNP. 
89. Mus pahari pahari Thomas, 1916: Bush Rat or Gairdner's Shrewmouse (Wroughton 1917b; Sharma 1990; Mukhopadhyay 1996, Singhal \& Mukhopadhyay 1998; Biswas et al. 1999; Chaudhuri \& Sarkar 2003)

This rat lives in the montane shrubs. N.A. Baptista collected one female (juvenile) from Pedong and one female from Sangser. It is a resident of NVNP. During the recent survey, this mouse was occasionally sighted at Thosum and Rechila at dusk.

Genus: Niviventer J.T. Marshall, 1976: Whitebellied Rats

90. Niviventer eha eha Wroughton, 1916: Smokebellied Rat (Sharma 1990).

This species lives in the coniferous and rhododendron forests and bamboo shrubs at high altitude. This nocturnal rat was not sighted during the current survey.

91. Niviventer fulvescens fulvescens Gray, 1847: Himalayan Chestnut White-bellied Rat (Wroughton, 1917b; Sharma 1990; Agrawal et al. 1992; <http:// zsienvis.nic.in/biodiversity_wb/Fauna/43.\%20 Mammal.doc $>$ downloaded on 20 October 2009).

This nocturnal rat is found in the evergreen broadleaved forests, shrubs and rocks. N.A. Baptista collected two males and one female from Nimbong and one male and two females from Pedong. It is said to be common in the study area, but it was not sighted during the recent survey.

Genus: Rattus Fischer de Waldheim, 1803: Old World Rats

92. Rattus nitidus nitidus Hodgson, 1845: Hodgson's Grey-bellied or Himalayan Rat (Blyth, 1863; Wroughton 1917b; Agrawal et al. 1992; <http:// zsienvis.nic.in/biodiversity_wb/Fauna/43.\%20 Mammal.doc $>$ downloaded on 20 October 2009)

It is common in the foothills, particularly in the vicinity of houses and fields. N.A. Baptista collected one female from Kalimpong, six males and one female from Nimbong, one male and one female from Pedong and three males and three females from Sangser. This nocturnal rat was not found during the recent survey.

93a. Rattus rattus rufescens Gray, 1837: Gray Common Indian House Rat (Wroughton, 1917b)

It is a common rat in the study area. N.A. Baptista collected 17 males, 14 females from Kalimpong, 28 males, 31 females from Nimbong, 30 males, 21 females from Pedong and 18 males, 14 females from Sangser. H. Khajuria also collected four sub-adult males from Tarkhola (1958). This nocturnal rat was not found during the recent surveys.

93b. Rattus rattus brunneusculus Hodgson, 1845: House Rat (Hinton, 1919; Agrawal et al. 1992; $<$ http://zsienvis.nic.in/biodiversity_wb/Fauna/43.\%20 Mammal.doc $>$ downloaded on 20 October 2009).

The house rat is quite common in the forests, fields, and residential complexes. N.A. Baptista collected two males and one female from Kalimpong, two males and two females from Nimbong, one male from Pedong, three males and one female from Sangser and $\mathrm{H}$. Khajuria collected four sub-adult males from Tarkhola in 1958. This nocturnal rat was not found during the recent survey.

93c. Rattus rattus (tanezumi) tistae Hinton, 1918: House rat (Agrawal et al. 1992; <http://zsienvis.nic. in/biodiversity_wb/Fauna/43.\%20Mammal.doc $>$ downloaded on 20 October 2009).

This species is very common in the forests as well as houses. N.A. Baptista collected three males and two females from Kalimpong, five males and one female from Nimbong, two males and four females from Pedong and one male from Sangser. This nocturnal rat was not found during the recent survey.

94. Rattus sikkimensis Hinton, 1919 [R. andamanensis in Wilson \& Reeder (2005): Sikkim Rat (Ellerman 1961; Molur et al. 2005).

The Sikkim Rat is a terrestral and arboreal animal and widespread across the Eastern Himalayas region. It is found in cultivated fields and adjacent forests up to an altitude of $2,000 \mathrm{~m}$. There were no previous records of this species in the study area. Only Molur et al. (2005) recorded this species in Kalimpong. It was not found during the current survey.

Genus: Vandeleuria Gray, 1842: Long-tailed Climbing Mouse

95. Vandeleuria oleracea dumeticola Hodgson, 1845: Indian Long-tailed or Hodgson's Tree-mouse (Wroughton 1917b; Ellerman 1947)

This long-tailed tree mouse is found in the foothills. N.A. Baptista collected one male from Kalimpong. This nocturnal mouse was not found during the current survey.

Suborder: Hystricognathi Tullberg, 1899: Hystricognath Rodents

Family: Hystricidae Fischer, 1817: Old World Porcupines

Genus: Hystrix Linnaeus, 1758: Old World 
Porcupines

96. Hystrix brachyura hodgsoni Gray, 1847: Himalayan Crestless Porcupine (Saha et al. 1992; Mukhopadhyay 1996, WWF-I Eastern Region 1997; Singhal \& Mukhopadhyay 1998; Singhal 1999; Chaudhuri \& Sarkar 2003; Chakraborty et al. 2008a; Chakraborty et al. 2008b).

The Himalayan Crestless Porcupine lives in various forest habitats and in the scrubby, open areas close to forest. It forages at night. Though earlier it was found in large numbers in the study area, it is now rare. During recent survey, this species was seen at Alubari area and its den or hole was observed near the moist hill forest and its quills were also collected. The population was decimated due to annual tribal hunting expeditions.

97. Hystrix indica indica Kerr, 1792: Indian Crested Porcupine (WWF-I Eastern Region 1997; Chaudhuri \& Sarkar 2003).

The crested porcupine lives in the forests and open areas from the foothills to an elevation of about $2,400 \mathrm{~m}$. It prefers the rocky hillsides. This nocturnal animal was not sighted and the indirect evidences were also not observed during the recent survey.

Order: Lagomorpha Brandt, 1855: Hares, Rabbits, Pikas

Family: Ochotonidae Thomas, 1897: Pikas

Genus: Ochotona Link, 1795: Pikas

98. Ochotona thibetana sikimaria Thomas, 1922: Moupin Pika (Khajuria \& Ghose 1970; Agrawal et al. 1992; Chaudhuri \& Sarkar 2003).

The crepuscular Moupin Pika occurs in the bamboo and rhododendron forests at higher altitudes. It is reported from Lachung $(2,622 \mathrm{~m})$ and Lachne $(2,865 \mathrm{~m})$ in North Sikkim (Ghose 1990) as well as Sandakphu, Darjeeling hills (Khajuria \& Ghose 1970). But there were no previous records of this species in the study area. Sighting of this species on the northern slope of the Neora top was reported by a birding team. The Moupin Pika was observed near its burrow during the morning hours. It has become endangered due to the destruction of the habitat, particularly rhododendron vegetation (Smith \& Boyer 2008).

Family: Leporidae Fischer, 1817: Hares and Rabbits

Genus: Lepus Linnaeus, 1758: Common Hares or Jackrabbits

99. Lepus nigricollis ruficaudatus I. Geoffroy,
1826: Indian Rufous-tailed or Black-naped Hare (Biswas \& Ghose 1982; WWF-I Eastern Region 1997; Chaudhuri \& Sarkar 2003; Chakraborty et al. 2008b).

This species is found at elevations up to $2,400 \mathrm{~m}$. Its preferred habitat is the depressions at the base of hills. It is a fairly common species in the study area. It was earlier recorded from Samsing and Tarkhola. Sighting of this diurnal hare was recorded during the current survey in NVNP. Its population is decimated due to annual tribal hunting expeditions.

\section{DISCUSSION AND CONCLUSIONS}

In comparison to N.A. Baptista's records of 29 mammalian species (22 genera) in Kalimpong hills, 99 mammalian species (see Table 1) with 93 subspecies under 10 orders, 26 families and 68 genera have been registered in the study area during the recent survey on the basis of direct sighting (31 species or $31.31 \%$ ), specimen collected earlier (25 species or $25.25 \%$ ), indirect evidences observed ( 7 species or $7.08 \%$ ) and secondary literature (36 species or $36.36 \%$ ). Two cervids (spotted and swamp deer) are already locally exterminated. So, out of 97 extant species, 71 species are recorded in KFD and 65 species are reported from NVNP. Carnivora is the most diverse order (32.32\%), followed by Rodentia (24.24\%), Chiroptera (23.23\%), Artiodactyla (9.10\%), Eulpotyphla (4.04\%), Primates (3.03\%), Pholidota (2.02\%), Scandentia (1.01\%) and Proboscidea (1.01\%). In fact, the rodents and chiropterans are mostly registered in KFD because these smaller mammals are very difficult to find out or trap in the inhospitable terrain and dense vegetation of NVNP.

The global conservation status of the registered species, as per IUCN Red List of Threatened Species 2008, is-Endangered: 5 (5.05\%); Vulnerable: 11 (11.11\%); Lower Risk-Near Threatened: 13 (13.13\%); Lower Risk-Least Concern: 63 (63.64\%); Data Deficient: 2 (2.02\%) and Not Evaluated: 5 (5.05\%). The national status of these species according to the Wildlife (Protection) Act, 1972 is- Schedule I: 21 (21.21\%); Schedule II: 29 (29.30\%); Schedule III: $6(6.06 \%)$; Schedule IV: 2 (2.02\%); Schedule V: $14(14.14 \%)$ and not scheduled: $27(27.27 \%)$. The nationally threatened species recorded in the study area are Ailurus fulgens, Amblonyx cinereus, Bos 
Table 1. Mammalian species registered in the study area

\begin{tabular}{|c|c|c|c|c|c|c|}
\hline Sno & Genus & Species & $\begin{array}{l}\text { Status as per } \\
\text { IUCN Red List }\end{array}$ & $\begin{array}{l}\text { Status as per } \\
\text { Indian Wildlife } \\
\text { (Protection) Act, } \\
1972 \text { amended up } \\
\text { to } 2002\end{array}$ & $\begin{array}{l}\text { Diurnal I } \\
\text { Nocturnal I } \\
\text { seen at all } \\
\text { times }\end{array}$ & $\begin{array}{l}\text { Information source } \\
\text { (Sighting / Evidence } \\
\text { / Citation from other } \\
\text { works) }\end{array}$ \\
\hline 1 & Episoriculus & caudatus & Least Concern & - & Nocturnal & Cited from literature \\
\hline 2 & Soriculus & nigrescens & Least Concern & - & Nocturnal & Sighted \\
\hline 3 & Suncus & murinus & Least Concern & - & Nocturnal & Cited from literature \\
\hline 4 & Euroscaptor & micrura & Least Concern & - & Nocturnal & $\begin{array}{l}\text { Concluded from indirect } \\
\text { evidence }\end{array}$ \\
\hline 5 & Tupaia & belangeri & Least Concern & - & Diurnal & Sighted \\
\hline 6 & Cynopterus & sphinx & Least Concern & Schedule V & Nocturnal & Cited from literature \\
\hline 7 & Rousettus & leschenaulti & Least Concern & Schedule V & Nocturnal & Cited from literature \\
\hline 8 & Rhinolophus & lepidus & Least Concern & - & Nocturnal & Cited from literature \\
\hline 9 & Rhinolophus & luctus & Least Concern & - & Nocturnal & Sighted \\
\hline 10 & Rhinolophus & pusillus & Least Concern & - & Nocturnal & Cited from literature \\
\hline 11 & Rhinolophus & rouxii & Least Concern & - & Nocturnal & Cited from literature \\
\hline 12 & Rhinolophus & sinicus & Least Concern & - & Nocturnal & Cited from literature \\
\hline 13 & Hipposideros & armiger & Least Concern & - & Nocturnal & Cited from literature \\
\hline 14 & Hipposideros & cineraceus & Least Concern & - & Nocturnal & Cited from literature \\
\hline 15 & Hipposideros & fulvus & Least Concern & - & Nocturnal & Cited from literature \\
\hline 16 & Hipposideros & pomona & Least Concern & - & Nocturnal & Cited from literature \\
\hline 17 & Barbastella & leucomelas & Least Concern & - & Nocturnal & Cited from literature \\
\hline 18 & Eptesicus & serotinus & Least Concern & - & Nocturnal & Sighted \\
\hline 19 & Nyctalus & noctula & Least Concern & - & Nocturnal & Cited from literature \\
\hline 20 & Pipistrellus & babu & Not Evaluated & - & Nocturnal & Cited from literature \\
\hline 21 & Pipistrellus & coromandra & Least Concern & - & Nocturnal & Cited from literature \\
\hline 22 & Pipistrellus & javanicus & Least Concern & - & Nocturnal & Cited from literature \\
\hline 23 & Pipistrellus & mimus & Not Evaluated & - & Nocturnal & Cited from literature \\
\hline 24 & Tylonycteris & pachypus & Least Concern & - & Nocturnal & Cited from literature \\
\hline 25 & Murina & cyclotis & Least Concern & - & Nocturnal & Cited from literature \\
\hline 26 & Murina & huttoni & Least Concern & - & Nocturnal & Cited from literature \\
\hline 27 & Murina & leucogaster & Data Deficient & - & Nocturnal & Cited from literature \\
\hline 28 & Murina & tubinaris & Least Concern & - & Nocturnal & Cited from literature \\
\hline 29 & Macaca & assamensis & Near Threatened & Schedule II, Part I & Diurnal & Sighted \\
\hline 30 & Macaca & mulatta & Least Concern & Schedule II, Part I & Diurnal & Sighted \\
\hline 31 & Semnopithecus & hector & Near Threatened & Schedule II, Part I & Diurnal & Cited from literature \\
\hline 32 & Canis & aureus & Least Concern & Schedule II, Part II & Nocturnal & Cited from literature \\
\hline 33 & Canis & indica & Not Evaluated & Schedule I, Part I & Nocturnal & Cited from literature \\
\hline 34 & Cuon & alpinus & Endangered & Schedule II, Part I & Nocturnal & $\begin{array}{l}\text { Concluded from indirect } \\
\text { evidence }\end{array}$ \\
\hline 35 & Vulpes & vulpes & Least Concern & Schedule II, Part II & Nocturnal & Cited from literature \\
\hline 36 & Catopuma & temminckii & Near Threatened & Schedule I, Part I & Nocturnal & Cited from literature \\
\hline 37 & Felis & chaus & Least Concern & Schedule II, Part II & Seen at all times & Sighted \\
\hline 38 & Prionailurus & bengalensis & Least Concern & Schedule I, Part I & Nocturnal & Sighted \\
\hline 39 & Prionailurus & viverrinus & Endangered & Schedule I, Part I & Nocturnal & Sighted \\
\hline 40 & Neofelis & nebulosa & Vulnerable & Schedule I, Part I & Nocturnal & Sighted \\
\hline 41 & Panthera & pardus & Near Threatened & Schedule I, Part I & Nocturnal & Sighted \\
\hline
\end{tabular}




\begin{tabular}{|c|c|c|c|c|c|c|}
\hline Sno & Genus & Species & $\begin{array}{l}\text { Status as per } \\
\text { IUCN Red List }\end{array}$ & $\begin{array}{l}\text { Status as per } \\
\text { Indian Wildlife } \\
\text { (Protection) Act, } \\
1972 \text { amended up } \\
\text { to } 2002\end{array}$ & $\begin{array}{l}\text { Diurnal / } \\
\text { Nocturnal I } \\
\text { seen at all } \\
\text { times }\end{array}$ & $\begin{array}{l}\text { Information source } \\
\text { (Sighting / Evidence } \\
\text { / Citation from other } \\
\text { works) }\end{array}$ \\
\hline 42 & Panthera & tigris & Endangered & Schedule I, Part I & Nocturnal & $\begin{array}{l}\text { Concluded from indirect } \\
\text { evidence }\end{array}$ \\
\hline 43 & Pardofelis & marmorata & Vulnerable & Schedule I, Part I & Nocturnal & Cited from literature \\
\hline 44 & Herpestes & edwardsii & Least Concern & Schedule II, Part II & Diurnal & Cited from literature \\
\hline 45 & Herpestes & auropunctatus & Not Evaluated & Schedule II, Part II & Seen at all times & Cited from literature \\
\hline 46 & Herpestes & urva & Least Concern & Schedule II, Part II & Seen at all times & Cited from literature \\
\hline 47 & Amblonyx & cinereus & Vulnerable & Schedule I, Part I & Seen at all times & Cited from literature \\
\hline 48 & Lutra & lutra & Near Threatened & Schedule II, Part II & Seen at all times & Cited from literature \\
\hline 49 & Lutrogale & perspicillata & Vulnerable & Schedule II, Part II & Seen at all times & Cited from literature \\
\hline 50 & Arctonyx & collaris & Near Threatened & Schedule I, Part I & Nocturnal & Cited from literature \\
\hline 51 & Martes & flavigula & Least Concern & Schedule II, Part II & Seen at all times & Sighted \\
\hline 52 & Martes & foina & Least Concern & Schedule II, Part II & Seen at all times & Sighted \\
\hline 53 & Mustela & altaica & Near Threatened & Schedule II, Part II & Seen at all times & Cited from literature \\
\hline 54 & Mustela & kathiah & Least Concern & Schedule II, Part II & Seen at all times & Sighted \\
\hline 55 & Mustela & strigidorsa & Least Concern & Schedule II, Part II & Seen at all times & Cited from literature \\
\hline 56 & Ailurus & fulgens & Vulnerable & Schedule I, Part I & Seen at all times & Sighted \\
\hline 57 & Melursus & ursinus & Vulnerable & Schedule I, Part I & Seen at all times & Cited from literature \\
\hline 58 & Ursus & thibetanus & Vulnerable & Schedule II, Part II & Nocturnal & Sighted \\
\hline 59 & Paguma & larvata & Least Concern & Schedule II, Part II & Nocturnal & Cited from literature \\
\hline 60 & Paradoxurus & hermaphroditus & Least Concern & Schedule II, Part II & Nocturnal & Cited from literature \\
\hline 61 & Prionodon & pardicolor & Least Concern & Schedule I, Part I & Nocturnal & Cited from literature \\
\hline 62 & Viverra & zibetha & Near Threatened & Schedule II, Part II & Nocturnal & $\begin{array}{l}\text { Concluded from indirect } \\
\text { evidence }\end{array}$ \\
\hline 63 & Viverricula & indica & Least Concern & Schedule II, Part II & Nocturnal & Cited from literature \\
\hline 64 & Elephas & maximus & Endangered & Schedule I, Part I & Seen at all times & Sighted \\
\hline 65 & Sus & scrofa & Least Concern & Schedule III & Seen at all times & Sighted \\
\hline 66 & Axis & axis & Least Concern & Schedule III & Diurnal & Cited from literature \\
\hline 67 & Rucervus & duvaucelii & Vulnerable & Schedule I, Part I & Diurnal & Cited from literature \\
\hline 68 & Rusa & unicolor & Vulnerable & Schedule III & Seen at all times & Sighted \\
\hline 69 & Muntiacus & vaginalis & Least Concern & Schedule III & Seen at all times & Sighted \\
\hline 70 & Bos & gaurus & Vulnerable & Schedule I, Part I & Diurnal & Sighted \\
\hline 71 & Hemitragus & jemlahicus & Near Threatened & Schedule I, Part I & Diurnal & Sighted \\
\hline 72 & Naemorhedus & goral & Near Threatened & Schedule III & Seen at all times & Sighted \\
\hline 73 & Capricornis & sumatraensis & Vulnerable & Schedule I, Part I & Seen at all times & $\begin{array}{l}\text { Concluded from indirect } \\
\text { evidence }\end{array}$ \\
\hline 74 & Manis & crassicaudata & Near Threatened & Schedule I, Part I & Nocturnal & Cited from literature \\
\hline 75 & Manis & pentadactyla & Endangered & Schedule I, Part I & Nocturnal & Cited from literature \\
\hline 76 & Callosciurus & pygerythrus & Least Concern & - & Diurnal & Sighted \\
\hline 77 & Dremomys & lokriah & Least Concern & - & Diurnal & Sighted \\
\hline 78 & Ratufa & bicolor & Near Threatened & Schedule II, Part II & Diurnal & Sighted \\
\hline 79 & Tamiops & macclellandi & Least Concern & - & Diurnal & Sighted \\
\hline 80 & Belomys & pearsonii & Data Deficient & Schedule II, Part II & Nocturnal & Cited from literature \\
\hline 81 & Hylopetes & alboniger & Least Concern & Schedule II, Part II & Nocturnal & Cited from literature \\
\hline 82 & Petaurista & elegans & Least Concern & Schedule II, Part II & Nocturnal & Cited from literature \\
\hline 83 & Petaurista & magnificus & Least Concern & Schedule II, Part II & Nocturnal & Cited from literature \\
\hline
\end{tabular}




\begin{tabular}{|l|l|l|l|l|l|l|}
\hline Sno & Genus & Species & $\begin{array}{l}\text { Status as per } \\
\text { IUCN Red List }\end{array}$ & $\begin{array}{l}\text { Status as per } \\
\text { Indian Wildlife } \\
\text { (Protection) Act, } \\
\mathbf{1 9 7 2} \text { amended up } \\
\text { to 2002 }\end{array}$ & $\begin{array}{l}\text { Diurnal I } \\
\text { Nocturnal I } \\
\text { seen at all } \\
\text { times }\end{array}$ & $\begin{array}{l}\text { Information source } \\
\text { (Sighting / Evidence } \\
\text { ICitation from other } \\
\text { works) }\end{array}$ \\
\hline 84 & Petaurista & nobilis & Near Threatened & Schedule II, Part II & Nocturnal & Cited from literature \\
\hline 85 & Petaurista & petaurista & Least Concern & Schedule II, Part II & Nocturnal & Cited from literature \\
\hline 86 & Neodon & sikimensis & Least Concern & Schedule V & Diurnal & Sighted \\
\hline 87 & Bandicota & bengalensis & Least Concern & Schedule V & Nocturnal & Sighted \\
\hline 87 & Mus & musculus & Least Concern & Schedule V & Nocturnal & Sighted \\
\hline 88 & Mus & pahari & Least Concern & Schedule V & Nocturnal & Sighted \\
\hline 90 & Niviventer & eha & Least Concern & Schedule V & Nocturnal & Cited from literature \\
\hline 91 & Niviventer & fulvescens & Least Concern & Schedule V & Nocturnal & Cited from literature \\
\hline 92 & Rattus & nitidus & Least Concern & Schedule V & Nocturnal & Cited from literature \\
\hline 93 & Rattus & rattus & Least Concern & Schedule V & Nocturnal & Cited from literature \\
\hline 94 & Rattus & sikkimensis & Not Evaluated & Schedule V & Nocturnal & Cited from literature \\
\hline 95 & Vandeleuria & oleracea & Least Concern & Schedule V & Nocturnal & Cited from literature \\
\hline 96 & Hystrix & brachyura & Least Concern & Schedule II, Part I & Nocturnal & Sighted \\
\hline 97 & Hystrix & indica & Least Concern & Schedule IV & Nocturnal & Cited from literature \\
\hline 98 & Ochotona & thibetana & Least Concern & - & Diurnal & Sighted \\
\hline 99 & Lepus & Least Concern & Schedule IV & Nocturnal & Sighted \\
\hline
\end{tabular}

gaurus, Canis aureus, Canis indica, Capricornis sumatraensis, Catopuma temminckii, Cuon alpinus, Elephas maximus, Lutra lutra monticola, Lutrogale perspicillata, Martes flavigula, Melursus ursinus, Naemorhedus goral, Neofelis nebulosa, Panthera pardus, Panthera tigris, Pardofelis marmorata, Soriculus nigrescens, Ursus thebetanus and Vulpes vulpes montana. All these twentyone threatened species are recorded in NVNP, whereas 15 of them are registered in KFD.

Of all the sites covered in the study area, Jaributi Valley (the richest natural repository of medicinal plants) and Alubari (earlier potatoes were cultivated here but after declaration of NP this forest village was shifted to the fringe area and the area was resuscitated through habitat improvement works) appeared to be most ideal places for viewing the wildlife movements in NVNP.

Some anthropogenic threats also pervade the study area. For example, the population of Darjeeling District was only 1,900 in the year 1850 and 2,200 in 1869 , which scaled up to $16,05,900$ in 2001 , the share of hill population being over 8.5 lakhs. The largescale emigration for the mushrooming tea industry, terrace cultivation and political reasons contributed to this rapid growth. Much of the natural forests, except those on the difficult terrains, were converted for settlement and commercial use, leading to soil erosion, landslides and loss of wildlife habitat and habitants. Decline in forest cover was observed in the Chel and Jaldhaka catchments of KFD. Infrastructural development works have recently been started in the pristine NVNP for expansion of eco-tourism. Threats are often caused by illegal cattle grazing, felling of timber, collection of fuelwood, fodder and Non-Timber Forest Produce (NTFP), retaliatory killings, the annual tribal hunting and poaching in the fragmented forests of KFD. As human habitations in and around NVNP are comparatively less in number combined with the physical constraints like inaccessibility and difficult terrain, biotic pressures are, however, not very acute in this area. This anthropogenic syndrome in KFD must be curbed for sustenance of the variegated wild denizens and restoration of the biodiversity values.

There is further scope for research on the sitespecific occurrence of the mammalian species in the study area with special emphasis on the smaller species like the chiropterans and rodents, preferably in the context of the known diversity in contiguous forests of the Eastern Himalaya in West Bengal, Sikkim, northeastern states in India, Bhutan and Nepal. 


\section{REFERENCES}

Abramov,A., C. Wozencraft \& W. Ying-xiang (2008). Mustela altaica. In: IUCN 2009. IUCN Red List of Threatened Species. Version 2009.2. <http://www.iucnredlist.org>. Downloaded on 19 November 2009.

Aggarwal, R.K., T. Kivisild, J. Ramadevi \& L. Singh (2007). Mitochondrial DNA coding region sequences support the phylogenetic distinction of two Indian wolf species. Journal of Zoological Systematics and Evolutionary Research 45(2): 163-172.

Agrawal, V.C., P.K. Das, S. Chakraborty, R.K. Ghose, A.K. Mandal, T.K. Chakraborty, A.K. Poddar, J.P. Lal, T.P. Bhattacharya \& M.K. Ghosh (1992). Mammalia, pp. 27 169. In: Director, Zoological Survey of India (ed.). State Fauna Series 3. Fauna of West Bengal, Part 1. Zoological Survey of India, Kolkata.

Alfred, J.R.B., A.K. Sanyal, A. Roy, S. Tiwari, S. Mitra \& B. Bhatta (2004). Biodiversity in West Bengal: A Demographic approach. Proceedings of the 7th Annual International Conference. MAP- India, 2004, New Delhi, $69 \mathrm{pp}$.

Alfred, J.R.B., A.K. Das \& A.K. Sanyal (2006). Animals of India-Mammals. Zoological Survey of India, Kolkata, $238 p p$.

Anderson, J. (1881). Catalogue of Mammalia in the Indian Museum, Calcutta, Part I. Indian Museum, Calcutta, 223pp.

Anderson, K. (1912). Catalogue of The Chiroptera in The Collection of the British Museum. $2^{\text {nd }}$ Edition. 1. Megachiroptera. British Museum (Natural History), London, 567pp.

Anonymous (1964). Sixth Working Plan for the Kalimpong Forest Division 1957-1958 to 1966-1967, Volume I. Calcutta: West Bengal Government Press, Alipore. 182pp.

Anonymous (1968). Forests and forest resources: a study of the inaccessible areas of Kalimpong Division, West Bengal. Calcutta: Office of the Chief Conservator of Forests, Planning and Statistical Cell, $\mathrm{x}+66 \mathrm{pp}$.

Anonymous (1998). Tiger conservation initiatives in West Bengal. Kolkata: Wildlife Wing, Forest Department, Government of West Bengal, 16pp.

Anonymous (2003). The Wildife (Protection) Act, 1972 as amended upto 2003. Wildlife Trust of India, New Delhi. Dehra Dun: Natraj Publishers, 218pp.

Anonymous (2008). Red Panda survey in Neora Valley National Park. Red Panda (ATREE - Eastern Himalaya Regional Office Newsletter) 1(2): 1.

Anonymous (2009). Tiger sighted in Gorumara NP after 25 years. Protected Area Update 15(3): 16.

Anonymous (2010). Protected Areas of West Bengal. Government of West Bengal, Directorate of Forests, Wildlife Wing, Kolkata. 37pp.

Athreya, V.R. \& A.J.T. Johnsingh (1995). Survey of the Clouded Leopard (Neofelis nebulosa) in North-East India. Wildlife Institute of India, Dehradun (Unpublished).
Bahuguna, N.C., S. Dhaundyal, P. Vyas \& N. Singhal (1998). Red panda in Darjeeling at Singalila National Park and adjoining forest: A status report. Small Carnivore Conservation (The Newsletter and Journal of the IUCN/ SSC Mustelid, Viverrid and Procyonid Specialist Group) 19: 11-12.

Bahuguna, N.C. \& J.K. Mallick (2004). Ungulates of West Bengal and its adjoining areas including Sikkim, Bhutan and Bangladesh, pp. 219-238. In: Sankar, K. \& S.P. Goyal (eds.). Ungulates of India, ENVIS Bulletin: Wildlife and Protected Areas 7(1), Wildlife Institute of India, Dehra Dun, 448pp.

Bahuguna, N.C. \& J.K. Mallick (2010). Handbook of the Mammals of South Asia. Natraj Publishers, Dehra Dun xxxiv+541pp+31plates.

Bates, P.J.J. \& D.L. Harrison (1997). Bats of the Indian Subcontinent. Harrison Zoological Museum, Kent, xiv $+268 \mathrm{pp}$.

Bhattacharya, S., A. Chowdhury \& G.G. Biswas (1997). A collaborative study on Gaurs (Bos gaurus H. Smith) in North Bengal, West Bengal, India. Final Report. World Wide Fund for Nature- India, Eastern Region, Calcutta, 79pp. (unpublished).

Bhattacharyya, T.P., A. Murmu, S. Chaudhuri \& P.C. Mazumder (2008). Status of four arboreal species of mammals in Darjeeling District, West Bengal, India. Records of the Zoological Survey of India: A Journal of Indian Zoology 108(3): 1-118.

Biswas, B. \& R.K. Ghose (1982). Progress report 1 on 'Pilot Survey' of the World Wildlife Fund-India/Zoological Survey of India collaborative project on the 'Status Survey of the Lesser Cats in Eastern India' (Project No. I.U.C.N. 1357- India). Zoological Survey of India, Calcutta, 52pp. (unpublished).

Biswas, B., R.K. Ghose \& D.K. Ghosal (1985). Progress report 2 on 'Pilot Survey' of the WWF-India/Zoological survey of India collaborative project on the 'Status Survey of the Lesser Cats in Eastern India'. Zoological Survey of India, Calcutta (unpublished).

Biswas, G.G., D. Das \& A. Mukhopadhyay (1999). Richness of mammalian species in the higher elevations of Neora Valley National Park. Zoos' Print 14(4): 10-12.

Blanford, W.T. (1891). The Fauna of British India, Including Ceylon and Burma - Mammalia-Part 2. Taylor and Francis, London, 251-617pp.

Blyth, E. (1863). Catalogue of the Mammalia in the Museum Asiatic Society. Savielle and Cranen- burgh, Bengal Printing Company, Calcutta, xiii+187pp.

Brandon-Jones, D. (2004). A taxonomic revision of the langurs and leaf monkeys (Primates: Colobinae) of South Asia. Zoos' Print Journal 19(8): 1552-1594.

Chakraborty, S., P. Dey, S. Tripathi, S. Jana \& A. Dey (2008a). Report on the status of Clouded leopard Neofelis nebulosa (Griffith) and Hodgson's flying squirrel Petaurista magnificus (Hodgson) in Neora Valley National Park, Darjeeling, West Bengal (Survey period 2006-2007). 
Project funded by Department of Forest, Government of West Bengal. Kolkata: Nature, Environment and Wildlife Society (NEWS), 52pp. (unpublished).

Chakraborty, S., V. Basu, P. Sen \& H. Nandy (2008b). Report on the status of Wild Dog Cuon alpines (Pallas) in Neora Valley National Park, District, Darjeeling, West Bengal. Society for Environment, Nature and Sustainable Ecosystems (SENSE), Kolkata, 28pp. (unpublished).

Chakraborty, S. \& V.C. Agrawal (1993). Mammals of West Bengal: An ecological aspect. ENVIS Newsletter 1(1): 2-3.

Chakraborty, T.K. \& R.K. Ghose (1984). A Note on the status of the flying squirrels of Darjeeling and Sikkim, India. Journal of the Bombay Natural History Society 80: 411.

Champion, H.G. \& S.K. Seth (1968). A Revised Survey of The Forest Types of India. Government of India Press, New Delhi, xxvii+404pp.

Chaudhuri, A.B. \& D.D. Sarkar (2003). Megadiversity Conservation: Flora, Fauna and Medicinal Plants of India's Hot Spots. Daya Publishing House, New Delhi, 300pp.

Chettri, N., E. Sharma, B. Shakya \& B. Bajracharya (2007a). Developing forested conservation corridors in the Kangchenjunga landscape, Eastern Himalaya. Mountain Research and Development 27(3): 211-214.

Chettri, N., R. Thapa \& B. Shakya (2007b). Participatory conservation planning in Kangchenjunga transboundary biodiversity conservation landscape. Tropical Ecology 48(2): 163-176.

Choudhury, A.U. (2001). An overview of the status and conservation of the red panda Ailurus fulgens in India, with reference to its global status. Oryx 35(3): 250-259.

Choudhury, A.U. (2002). Distribution and conservation of the Gaur Bos gaurus in the Indian Subcontinent. Mammal Review 32(3): 199-226.

Corbet, G.B. \& J.E. Hill (1992). The Mammals of the Indomalayaregion: A systematic review. Oxford University Press, Oxford, 488pp.

Cowan, J.M. (1929). The forests of Kalimpong - an ecological account. Records of the Botanical Survey of India 12(1): $1-74$.

Dalgliesh, G. (1906). Notes and observations on mammals collected and observed in the Darjeeling District. Journal of the Bombay Natural History Society 17(1): 122-127.

Das, P.K. (2003). Studies on some Indian Chiroptera from West Bengal. Records of Zoological Survey of India (Occasional Paper) 217: 1-164.

Dasgupta, B. (1991). A "mad elephant" in Darjeeling. Journal of Bengal Natural History Society 10(1): 83-86.

Davis, S.D., V.H. Heywood \& A.C. Hamilton (eds.) (1995). Centres of Plant Diversity: A Guide and Strategy for Their Conservation, II. Asia, Australasia and The Pacific. Worldwide Fund for Nature (WWF) and IUCN (The World Conservation Union), IUCN Publications, University of Cambridge. xiv $+578 \mathrm{pp}$, maps and photographs.

Dey, P. (2009). Neora Valley National Park: Mountain retreat of secretive cats. Environ 10(1): 8-15.

Dey, S.C. (1991a). Depredation by wildlife in the fringe areas of North Bengal forests with special reference to elephant damage. Indian Forester 117(10): 901-908.

Dey, S.C. (1991b). Marauding elephants of North Bengal. West Bengal 33(17): 512-517.

Dobson, G.E. (1876). Monograph of the Asiatic Chiroptera and Catalogue of The Species of Bats in The Collection of The Indian Museum, Calcutta. Indian Museum, London, 228pp.

Dutt-Mazumdar, S. (1955). Wildlife of Darjeeling Hills. Journal of the Bengal Natural History Society 27(4): 155159.

Ellerman, J.R. (1947). A key to the rodentia inhabiting India, Ceylon, and Burma, based on collections in the British Museum - Part II. Journal of Mammalogy 28(4): 357-387.

Ellerman, J.R. (1961). The Fauna of India, Including Pakistan, Burma and Ceylon: Mammalia, $2^{\text {nd }}$ Edition, Volume 3; Rodentia (Part 1 \& 2). Zoological Survey of India. Calcutta, India. 1: 1-482; 2: 483-884.

Ellerman, J.R. \& T.C.S. Morrison-Scott (1951). Checklist of Palaearctic and Indian Mammals 1758 to 1946. British Museum (Natural History), London, 809pp.

Fooden, J. (1982). Taxonomy and evolution of the Sinica group of macaques: 3. Species and subspecies accounts of Macaca assamensis. Fieldiana Zoology (New Series) 10: $1-52$.

Fooden, J. (2000). Systematic review of the rhesus macaque, Macaca mulatta (Zimmermann, 1780). Fieldiana Zoology (New Series) 96: 1-180.

Fry, T.B. (1923). A collection of mammals made by H. Stevens in the Darjeeling District. Journal of the Bombay Natural History Society 29(1): 90-92.

Gadgil, M. \& V.M. Meher-Homji (1987). Role of protected areas in conservation, pp. 143-159. In: Chopra, V.L. \& T.N. Khoshoo (eds.). Conservation for Productive Agriculture. Indian Council of Agricultural Research, New Delhi.

Ghose, D., S. Molur \& K. Leus (2007). Report of the Red Panda pre-PHVA meeting, 17-19 February 2007. WWFIndia, Deorali, Gangtok. Sikkim.

Ghose, R.K. (1964). A new rat of the genus Rattus Fischer, 1803 (Mammalia: Rodentia), from Darjiling District, West Bengal, India. Proceedings of Zoological Society of Calcutta 17(2): 193-197.

Ghose, R.K. (1976). A new record of the Shrew, Suncus murinus griffithi (Horsfield) from Darjeeling district, West Bengal. Journal Zoological Society of India 26: 151-152.

Ghose, R.K. (1985). Ecological observation on the Neora Valley, Darjeeling District, West Bengal. Journal of the Bengal Natural History Society (New Series) 3(2): 84-98.

Ghose, R.K. (1990). Deterioration of the habitat of the Moupin pika, Ochotona thibetana sikimaria Thomas, in Sikkim, India. Records of the Zoological Survey of India 87(4): 329.

Ghose, R.K. \& D.K. Ghosal (1969). Further observation on the Darjeeling White-bellied Rat, Rattus niviventer monticola Ghose. Labdev Journal of Science and Technology 7-8(2): 173. 
Ghose, R.K. \& S. Guha Roy (1972). Morphometric variation in the Sikkim Vole, Pitymys sikimensis (Hodgson) from Darjeeling district, West Bengal, India. Journal of the Zoological Society of India 24: 29-37.

Ghose, R.K. \& S.S. Saha (1981). Taxonomic review of the Hodgson's Giant Flying Squirrel, Petaurista magnificus (Hodgson) [Sciuridae: Rodentia] with description of a new subspecies from Darjeeling district, West Bengal, India. Journal of the Bombay Natural History Society 78(1): 93102.

Ghose, R.K. \& T.K. Chakraborty (1983). A note on the status of the Flying Squirrels of Darjeeling and Sikkim. Journal of the Bombay Natural History Society 80(2): 411-412.

Ghose, R.K. \& T.P. Bhattacharya (1995). New distributional record of Petaurista fulvinus Wroughton, 1911 (Mammalia: Rodentia: Sciuridae), with comments on its taxonomic status. Journal of the Bombay Natural History Society 92(2): 254-255.

Ghosh, A.K. (1992). The State of West Bengal: An overview, pp. 1-26. In: Director, Zoological Survey of India (ed.). State Fauna Series 3. Fauna of West Bengal, Part 1. Calcutta: Zoological Survey of India.

Ghosh, A.K., D. Deb \& P. Sanyal (2008). Chapter 8: Forests and Wildlife, pp. 92-108. In: Ghosh, A.K. (ed.) Status of Environment in West Bengal: A Citizen's Report. Society for Environment and Development (ENDEV), Kolkata, 262pp.

Ghosh, D.K. (1997). Ninth Working Plan, Kalimpong Division, 1997-98 to 2017-18, Vol. 1. Darjeeling: Working Plans Division, Forest Directorate, Government of West Bengal.

Gray, J.E. (1842). Descriptions of some new genera and fifty unrecorded species of Mammalia. Annals and Magazine of Natural History 10: 255-267.

Groves, C. (2003). Taxonomy of ungulates of the Indian Subcontinent. Journal of the Bombay Natural History Society 100(2-3): 341-361.

Gupta, A.C. (1958). Gorumara game sanctuary. Journal of the Bengal Natural History Society 29(4): 132-139, 1 map, figs. 1-4.

Han, K.H, J.W. Duckworth \& S. Molur (2008). Tupaia belangeri. In: IUCN 2009. IUCN Red List of of India, Burma and Ceylon. Journal of the Bombay Natural History Society 26: 59-86.

Harding, R. (2006). Roy Harding - Grandpa's schooldays. Kalimpong Association (UK) Newsletter Spring 2006: 6-9.

Hill, J.E. (1983). Bats (Mammalia: Chiroptera) from IndoAustralia. Bulletin British Museum of Natural History (Zoology) 45(3): 103-208.

Hinton, M.A.C. (1919). Scientific results from the mammal survey. No. 18(2). Report on the house rats of India, Burma and Ceylon. Journal of the Bombay Natural History Society 26: 384-416.

Hinton, M.A.C. (1922). Scientific results from the mammal survey. No. 32. Notes on Soriculus nigrescens and its subspecies. Journal of the Bombay Natural History Society 28: 1052-1055.
Horsfield, T. (1851). A catalogue of the Mammalia in the Museum of the Hon. East India Company. J.\&H. Cox, London.

Hunter, W.W. (1876). A statistical account of Bengal. 10. Districts of Darjeeling and Jalpaiguri, and State of Kuch Behar. Trubner \& Co., London.

Islam, M.Z. \& A.R. Rahmani (2004). Important bird areas in India: Priority sites for conservation. Indian Bird Conservation Network: Bombay Natural History Society and Bird Life International, Cambridge, UK, xviii+1133pp.

Jha, A. \& R.K. Avasthe (undated). Mammals of Sikkim. WWF-India-Department of Science and Technology, Sikkim Project. <http://sikkim.nic.in/sikkimroot/html/ wwf3.pdf $>$. Downloaded on 20 February 2009.

Johnson, M.K., R.C. Belden and D.R. Aldred (1984). Differentiating mountain lion and bobcat scats. Journal of Wildlife Management 48: 239-244.

Khajuria, H. (1959). Field observations on the habits of the Himalayan striped squirrel and the Sikkim vole in Darjeeling district, West Bengal. Proceedings of the First All-India Congress of Zoology, 24-28 October, 1959, Part 2: $245-246$.

Khajuria, H. (1966). Some observations on the habits of the Assamese macaque. Proceedings of the Second All-India Congress of Zoology, 1962, Part 2: 284.

Khajuria, H. \& R.K. Ghose (1970). On a collection of small mammals from Darjeeling district, West Bengal. Journal of the Bengal Natural History Society 36(1): 15-36.

Koopman, K.F. (1989). Distributional patterns of IndoMalayan bats (Mammalia: Chiroptera). American Museum Novitates 2942: 1-19.

Major, M., M.K. Johnson, W.S. Davis \& T.F. Kellog (1980). Identifying scats by recovery of bile acids. Journal of Wildlife Management 44: 290-293.

Majumdar, N.C., B. Krishna \& M.C. Biswas (1984). Vegetation of the Neora and adjacent regions in Kalimpong Forest Division, West Bengal. Journal of Economic and Taxonomic Botany 5(5): 1013-1025.

Mallick, J.K. (2007). Endemic mammals of West Bengal. West Bengal 49(10-11): 53-55.

Mallick, J.K. (2009). Endemic Marsh Mongoose of east Kolkata wetlands: a status report. Journal of Threatened Taxa 1(4): 215-220.

Mallick, J.K. (2010a). Neora Valley - a new short-listed world heritage site. Tigerpaper 37(3): 12-16.

Mallick, J.K. (2010b). Status of Red Panda Ailurus fulgens in Neora Valley National Park, Darjeeling District, West Bengal, India. Small Carnivore Conservation 43: 30-36.

Mallick, J.K. (2010c). Past and present status of the Indian Tiger in northern West Bengal, India: an overview. Journal of Threatened Taxa 2(3): 739-752.

Matthews, W.H. (1934). Records of some clouded leopards (Neofelis nebulosa) in the Darjeeling District. Journal of the Bombay Natural History Society 37(4): 946-947.

Mitra, S. (2000a). Assamese macaque Macaca assamensis. The Twilight 2(2-3): 51-53. 
Mitra, S. (2000b). Eco-behavioural study of the Assamese macaque. $\mathrm{PhD}$ Thesis. Burdwan University, India. (unpublished).

Mitra, S. (2000c). Interspecific interactions in Macaca assamensis. Cheetal 39(3-4): 67-70.

Mitra, S. (2001). Assamese macaque in West Bengal. West Bengal 43(20): 33.

Mitra, S. (2002). Diet and feeding behavior of Assamese macaque (Macaca assamensis). Asian Primates 8(1-2): $12-14$.

Mitra, S. (2003). Gorals (Nemorhaedus goral hodgsoni) in Mahananda wildlife sanctuary, West Bengal, India. Zoos Print Journal 18(9): 1199-1201.

Mitra, S. (2003-2004). Foods consumed by Assamese macaques in West Bengal, India. Asian Primates 8(3-4): 17-20.

Mitra, S. (2004). In dire straits: The crisis of the Bengal Elephants. Panda (WWF-India Newsletter) October: 1920.

Mitra, S. \& J.R.B. Alfred (2002). Population ecology of Macaca assamensis McClelland, 1839 in Darjeeling. XIX Congress of International Primatological Society (Abstract), 219pp.

Mitra, S. \& J.R.B. Alfred (2007). Reproductive behaviour of the Assamese Macaque (Macaca assamensis) in Darjeeling District, India. Records of the Zoological Survey of India: A Journal of Indian Zoology 107(4): 1-128.

Molur, S., G. Marimuthu, C. Srinivasulu, S. Mistry, A.M. Hutson, P.J.J. Bates, S. Walker, K.P. Priya \& A.R.B. Priya (eds.) (2002). Status of South Asian Chiroptera: Conservation Assessment and Management Plan (C.A.M.P.) Workshop Report, 2002. Coimbatore: Zoo Outreach Organisation, CBSG South Asia and WILD, India, 320pp.

Molur, S., D. Brandon-Jones, W. Dittus, A. Eudey, A. Kumar, M. Singh, M.M. Feeroz, M. Chalise, P. Priya \& S. Walker (2003). Status of South Asian Primates: Conservation Assessment and Management Plan (C.A.M.P.) Workshop Report, 2003. Coimbatore: Zoo Outreach Organisation/ CBSG-South Asia, India. viii+432pp.

Molur, S., C. Srinivasulu, B. Srinivasulu, S. Walker, P.O. Nameer \& L. Ravikumar (2005). Status of South Asian Non-volant Small Mammals: Conservation Assessment and Management Plan (C.A.M.P.) Workshop Report. Coimbatore: Zoo Outreach Organisation/CBSG-South Asia, India, 618pp.

Molur, S. \& A. Chhangani (2008). Semnopithecus hector. In: IUCN 2011. IUCN Red List of Threatened Species. Version 2011.2. <www.iucnredlist.org>. Downloaded on 08 February 2010.

Mukherjee, A.R. (1995). Forest Resources Conservation and Regeneration: A study of West Bengal Plateau. Concept Publishing Company, 185pp.

Mukherjee, R., D.K. Ghosh \& S.S. Saha (1980). Wild encounters on the Darjeeling Himalays. Cheetal 21(2-3): 33-35.

Mukherjee, R., S.S. Saha \& R.K. Ghose (1982). Further wild encounters in Darjeeling Himalaya. Cheetal 23(4): 35-37.
Mukherjee, R.P., S. Chaudhuri \& A. Murmu (1995). Population survey of south-Asian non-human primates in and around Darjeeling. Primate Report 41: 23-32.

Mukhopadhyay, A. (1996). Biodiversity of Animal Life of Neora Valley National Park: Mammals and Other Vertebrates (Part II). Department of Zoology, University of North Bengal, Darjeeling, West Bengal. (unpublished).

Murmu, A., S. Chaudhuri, P.C. Mazumder \& B. Talukder (2004). Status of Assamese Macaque, Macaca assamensis, in Darjeeling district, West Bengal, India. Records of the Zoological Survey of India 103(1-2): 1-186.

Myers, N., R.A. Mittermeier, C.G. Mittermeier, G.A.B. da Fonseca \& J. Kent (2000). Biodiversity hotspots for conservation priorities. Nature 403: 853-858.

Nandy, H. (2006a). Threatened mammals of West Bengal. West Bengal 48(10): 25-30.

Nandy, S. (2006b). Wild cats of West Bengal. West Bengal 48(10): 13-18.

Nanjappa, V. (2008). Elephants of North Bengal. Wildlife Times. <http://www.wildlifetimes.com/forums/viewtopic. php? $\mathrm{p}=332 \mathrm{~s}$ sid $=0306 \mathrm{ed} 815 \mathrm{c} 658 \mathrm{~b} 7 \mathrm{c} 0569 \mathrm{e} 8 \mathrm{bb} 15 \mathrm{c} 640 \mathrm{e} 9>$ Downloaded on 10 December 2009.

Olson, D.M. \& E. Dinerstein (1998). The Global 200: A Representation Approach to Conserving the Earth's Most Biologically Valuable Ecoregions. Conservation Biology 12 (3): 502-515.

O'Malley, L.S.S. (1907). Bengal District Gazetteer: Darjeeling. Gyan Publishing House, New Delhi, xiv+231pp.

Pocock, R.I. (1908). Notes upon some species and geographical races of Serows (Capricornis) and Gorals (Naemorhedus) based upon specimens exhibited in the Society's gardens. Proceedings of the Zoological Society of London 1908: 173-202.

Pradhan, S. (1998). Research Study on the Biological Studies of the Red Panda, Ailurus fulgens, in the Singalila National Park, Darjeeling and its adjoining areas (1993-96). Final Report. Darjeeling: PG Department of Zoology, Darjeeling Government College, West Bengal, 74pp.

Pradhan, S. (1999). Observations of the Red Panda (Ailurus fulgens) in the Singhalila Park, Darjeeling, India. Small Carnivore Conservation 21: 6-7.

Pradhan, S. (2006). Conserving the enigmatic Red Panda. West Bengal 48(10): 31-33.

Pradhan,S.\& R.Bhujel(unpub.).Biodiversityof the Darjeeling Himalaya. Draft. (<http://www.resourceshimalaya.org $>$ downloaded on 20 January 2009).

Pradhan, S., G.K. Saha \& A.J. Khan (2001a). Ecology of the red panda Ailurus fulgens in the Singhalila National Park, Darjeeling, India. Biological Conservation 98(1): 11-18.

Pradhan, S., G.K. Saha \& A.J. Khan (2001b). Food habits of the red panda, Ailurus fulgens in the Singhalila National Park, Darjeeling, India. Journal of the Bombay Natural History Society 98(2): 224-230.

PRAGYA (2007). Preliminary identification of IPAs for medicinal plants in the Himalayas: Country Report: India, $54 \mathrm{pp}$. 
Prince, M. (2003). Birding trip report: North Bengal, India; November 2002, pp. 1-24. <http://docs.google.com/ gview? $\mathrm{a}=\mathrm{v} \& \mathrm{q}=$ cache $>$. Downloaded on 20 October 2009.

Raha, A.K. (1996). Wildlife conservation in West Bengal: A decade at a glance. Kolkata: Wildlife Wing, Forest Department, Government of West Bengal, 58pp.

Rai, P.C. \& A.P. Das (2004). Ethnobotanical significance of the flora of Neora Valley National Park in the district of Darjeeling, West Bengal (India). Bulletin of the Botanical Survey of India 46(1-4): 337-355.

Ranganathan, J., K.M.A. Chan, K.U. Karanth \& J.L.D. Smith (2008). Where can tigers persist in the future? A landscape-scale, density-based population model for the Indian subcontinent. Biological Conservation 141(1): $67-$ 77.

Rishi, V. (2009). Badal: The clouded leopard. Environ 10(2): 20-29.

Saha, S.S., S. Chattopadhyay, R.P. Mukherjee \& J.R.B. Alfred (1992). Wildlife and its conservation in West Bengal, pp. 419-443. In: Director, Zoological Survey of India (ed.). State Fauna Series 3. Fauna of West Bengal, Part 1. Zoological Survey of India, Calcutta.

Saha, S.S. \& N. Singhal (1996). Mammalian specimens of Bengal Natural History Museum, Darjeeling. Darjeeling: Department of Forest (Wildlife Wing), Government of West Bengal, 69pp.

Saha, G.K. \& S. Mazumdar (2008). Threatened mammals of India: Ecology and management. Daya Publishing House, New Delhi, 162pp.

Sanyal, P. (2006). Tiger crisis- Anthropogenic or natural. Annual Issue (Retired IFS Officers Association, West Bengal): 38-39.

Sanyal, A.K., Ramakrishna \& J.R.B. Alfred (2007). Faunal resources in West Bengal. West Bengal 49(10-11): 38-48.

Sathyakumar, S. (2001). Status and management of Asiatic Black Bear and Himalayan Brown Bear in India. Ursus 12: 21-30.

Sclater, W.L. (1891). Catalogue of Mammalia in the Indian Museum, Calcutta, Part II. Indian Museum, Calcutta, xxix $+375 p p$.

Servheen, C., S. Herrero \& B. Peyton (1999). Bears. Status Survey and Conservation Action Plan. IUCN/SSC Bear and Polar Bear Specialist Groups. IUCN, Gland, Switzerland and Cambridge, UK, 309pp.

Sharma, B.R. (1990). First Management Plan for the Neora Valley National Park in Darjeeling District, West Bengal, for the period 1990-1991 to 2000-2001. Darjeeling: Directorate of Forests, Government of West Bengal, 198pp.

Sharma, E. \& N. Chettri (2005). ICIMOD's Transboundary Biodiversity Management Initiative in the Hindu KushHimalayas. Mountain Research and Development 25(3): 278-281.

Shebbeare, E.O. (1915). Altitude to which elephants ascend. Journal of the Bombay Natural History Society 23(4): 770.

Shebbeare, E.O. (1933). The episode of the Darjeeling Bison.
Journal of the Bengal Natural History Society 8(2): 65-67. Singhal, N. (1999). Neora Valley National Park at a Glance. Jalpaiguri: Divisional Forest Officer, Wildlife Division-II.

Singhal, N. \& A. Mukhopadhyay (1998). Management Plan of Neora Valley National Park, West Bengal for the period 1998-99 to 2007-08. Wildlife Circle, Govt. of West Bengal. $159 \mathrm{pp}$.

Sinha, Y.P. (1973). Taxonomic studies on the Indian Horseshoe Bats of the genus Rhinolophus Lacepede. Mammalia 37: 603-630.

Sinha, Y.P. (1990). Occurrence of the pipistrelle bat, Pipistrellus peguensis Sinha, 1969 in Darjeeling, West Bengal, India. Geobios New Reports (An international Biannual Journal of Life Sciences), Jodhpur 9: 171.

Smith, A.T. \& A.F. Boyer (2008). Ochotona thibetana. In: IUCN 2009. IUCN Red List of Threatened Species. Version 2009.2. <http://iucnredlist.org>. Downloaded on 02 December 2009.

Southwick, C.H., A. Ghosh \& C.B. Louch (1964). A roadside survey of rhesus monkeys in Bengal. Journal of Mammalogy 45(3): 443-448.

Stattersfield, A.J., M.J. Crosby, A.J. Long \& D.C. Wege (1998). Endemic Bird Areas of the World: Priorities for Biodiversity Conservation. Cambridge: The Burlington Press Ltd, U.K.

Subba, S. (2000). Trade in Musk and Bear Bile in India. TRAFFIC-India/WWF-India.

Sur, C.M. (1957). Wild dogs in the Darjeeling District. Indian Forester 83(7): 237-239.

Thomas, O. (1915). Scientific Results from the Mammal Survey. No. 11. A.- On pipistrels of the genera Pipistrellus and Scotozous. Journal of the Bombay Natural History Society 24: 29-34.

Thomas, O. (1916a). Scientific Results from the Mammal Survey. No. 13. A. On Muridae from Darjiling and the Chin Hills. Journal of the Bombay Natural History Society 24: 404-415.

Thomas, O. (1916b). Scientific results from the mammal survey. No. 14. A. A new bat of the genus Murina from Darjiling. Journal of the Bombay Natural History Society 24: 639-640.

Tickell, S.R. (1843). Notes on a curious species of Tiger or Jaguar, killed near the snowy range, north of Darjeeling. Journal of the Asiatic Society of Bengal 12(141): 814-816.

Tikader, B.K. (1983). Threatened animals of India. Zoological Survey of India, Calcutta, 307pp.

Tiwari, K.K. (1982). Report on population census of Rhesus Macaque and Hanuman Langur of India. New Delhi: Department of Science and Technology. (unpublished).

Topal, G. (1970). On the systematic status of Pipistrellus annectans Dobson, 1871 and Myotis primula Thomas, 1920 (Mammalia). Annales Historico-Naturales Musei Nationalis Hungarici 62: 373-379.

UNESCO World Heritage Centre (2009). Neora Valley National Park. <http://whc.unesco.org/en/ tentativelists/5447>. Downloaded on 29 July 2009. 
Vié, J.-C., C. Hinton-Taylor \& S.N. Stuart (eds.) (2009). Wildlife in a changing world-An analysis of the 2008 IUCN Red List of Threatened Species. IUCN. Gland: Switzerland. 180pp.

Wangchuk, S. (2007). Maintaining ecological resilience by linking protected areas through biological corridors in Bhutan. Tropical Ecology 48(2): 176-187.

Wilson, D.E. \& D.M. Reeder (eds.). (2005). Mammal Species of the World. A Taxonomic and Geographic Reference (3rd edition). Johns Hopkins University Press, 142pp.

Wright, A. (2004). History of WWF-India: Eastern India Region. Panda October: 13-14.

Wroughton, R.C. (1916a). Bombay Natural History Society's Mammal Survey of India, Burma and Ceylon. Report No. 23. Sikkim and Bengal Terai. Journal of the Bombay Natural History Society 24(3): 468-493.

Wroughton, R.C. (1916b). Bombay Natural History Society's Mammal Survey of India, Burma and Ceylon. Report No. 26. Darjiling District. Journal of the Bombay Natural History Society 24(4): 773-782.
Wroughton, R.C. (1917a). Bombay Natural History Society's Mammal Survey of India, Burma and Ceylon. Report No. 27. Bhutan Duars. Journal of the Bombay Natural History Society 25(1): 63-71.

Wroughton, R.C. (1917b). Bombay Natural History Society's Mammal Survey of India, Burma and Ceylon. Report No. 28. Kalimpong (Darjiling). Journal of the Bombay Natural History Society 25(2): 274-278.

WWF-I (Eastern Region) (1997). Leopard Study Report. Calcutta: WWF-I, Eastern Region. 51pp+Annexures. (unpublished).

WWF-US, Asia Program (2005). Ecosystem profile: Eastern Himalayas Region. Final Version, February 2005, 97pp. (unpublished).

Yadav, V.K. (2001). Wildlife conservation in West Bengal. Banabithi, Wildlife Issue, October: 25-29.

Yadav, V.K. (2004). The denizens of Darjeeling hills. Banabithi, Wildlife Issue, October: 34-36.

Yadav, V.K. (2005). Tiger conservation in West Bengal. West Bengal 47(9): 12-17. 